\author{
А.А. Зимирова, М.В. Поспелов, А.В. Иванова, Л.Н. Дмитриева, Е.А. Чу- \\ мачкова, В.А. Сафронов, И. Г. Карнаухов, С. А. Щербакова, В. В. Кутырев
}

\title{
Анализ динамики эпидемического процесса COVID-19 в мире за неделю с 11.09.2021 г. по 17.09.2021 г.
}

ФКУЗ Российский научно-исследовательский противочумный институт «Микроб» Роспотребнадзора, Саратов, Российская Федерация

В обзоре представлен анализ эпидемиологической ситуации в странах мира по COVID-19, за неделю с 11.09.2021 г. по 17.09.2021 г.

Анализ проведен на основании данных следующих ресурсов:

1. www.worldometers.info/coronavirus/

2. tass.ru/pandemiya-covid-19

3. www.skyscanner.ru/travel-restrictions

4. reopen.europa.eu/en/map/LVA/7001

5. intelyse.com/coronavirus-travel-restrictions/

6.gisanddata.maps.arcgis.com/apps/dashboards/bda7594740fd40299423467b48e9ecf

Всего в мире зарегистрировано 227064424 случая заболевания (29681 на 1 млн. населения); прирост за неделю составил 3881581 случай (507,4 на 1 млн. населения) - 1,7\%.

Всего в мире зарегистрировано 4671135 летальных исходов (610,6 на 1 млн. населения); прирост за неделю составил 64526 случаев $(8,4$ на 1 млн. населения) $-1,4 \%$.

За неделю с 11 по 17 сентября 2021 г. показатель прироста новых случаев в сравнении с неделей с 4 по 10 сентября 2021 г. снизился и составил $1,7 \%$ (рисунок 1; таблица 1). Недельный прирост числа летальных исходов за анализируемую неделю продемонстрировал увеличение в сравнении с прошлой неделей $-1,4 \%$. 


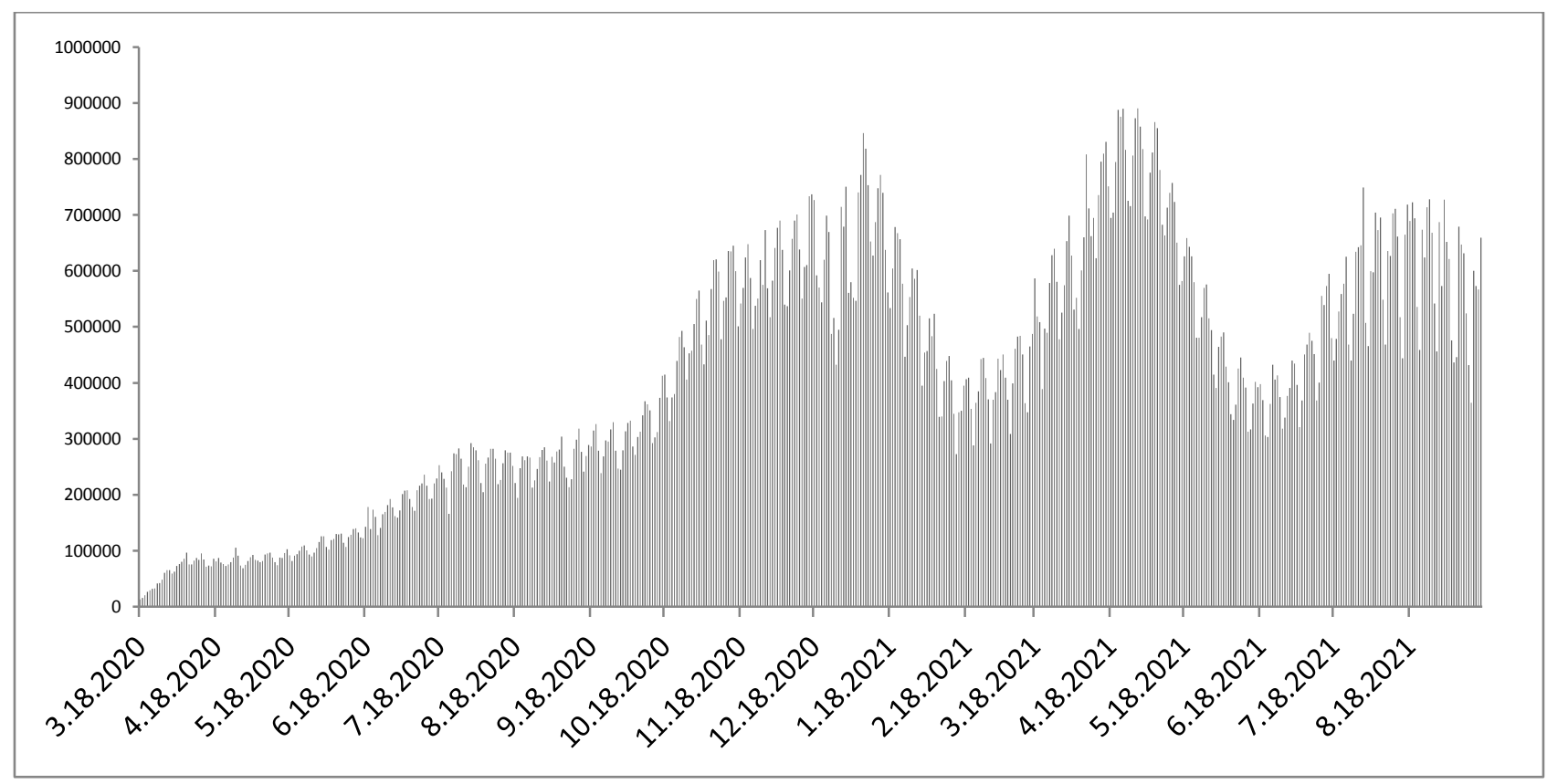

Рисунок 1 - Ежедневный прирост подтвержденных случаев в мире

Таблица 1 - Еженедельный прирост случаев за последние полгода

\begin{tabular}{|c|c|c|c|c|c|}
\hline Неделя & $\begin{array}{c}\text { Недельный } \\
\text { прирост } \\
\text { (случаев) }\end{array}$ & $\begin{array}{c}\text { Недельный } \\
\text { прирост (\%) }\end{array}$ & Неделя & $\begin{array}{c}\text { Недельный } \\
\text { прирост } \\
\text { (случаев) }\end{array}$ & $\begin{array}{c}\text { Недельный } \\
\text { прирост (\%) }\end{array}$ \\
\hline $20-26$ марта & 3610517 & 2,9 & $19-25$ июня & 2576278 & 1,5 \\
\hline $\begin{array}{c}27 \text { марта }-2 \\
\text { апреля }\end{array}$ & 4154907 & 3,3 & $\begin{array}{c}26 \text { июня }-2 \\
\text { июля }\end{array}$ & 2650167 & 1,5 \\
\hline $3-9$ апреля & 4286980 & 3,3 & $3-9$ июля & 2927889 & 1,6 \\
\hline $10-16$ апреля & 5061518 & 3,8 & $10-16$ июля & 3363018 & 1,8 \\
\hline $17-23$ апреля & 5540022 & 4,0 & $17-23$ июля & 3656571 & 1,9 \\
\hline $24-30$ апреля & 5730784 & 4,0 & $24-30$ июля & 3978967 & 2,1 \\
\hline $1-7$ мая & 5522787 & 3,7 & $\begin{array}{c}31 \text { июля }-6 \\
\text { августа }\end{array}$ & 4295399 & 2,2 \\
\hline $8-14$ мая & 5190039 & 3,3 & $\begin{array}{c}7-13 \text { авгу- } \\
\text { ста }\end{array}$ & 4386968 & 2,3 \\
\hline $15-21$ мая & 4444155 & 2,7 & $\begin{array}{c}14-20 \text { авгу- } \\
\text { ста }\end{array}$ & 4416659 & 2,2 \\
\hline $22-28$ мая & 3514812 & 2,1 & $\begin{array}{c}21-27 \text { авгу- } \\
\text { ста }\end{array}$ & 4617376 & 2,2 \\
\hline 29 мая - 4 & 3254304 & 1,9 & $\begin{array}{c}28 \text { августа - } \\
3 \text { сентября }\end{array}$ & 4457642 & 2,1 \\
\hline июня & \multicolumn{4}{|l}{} \\
\hline
\end{tabular}




\begin{tabular}{|c|c|c|c|c|c|}
\hline $5-11$ июня & 2745583 & 1,6 & $\begin{array}{c}4-10 \text { сен- } \\
\text { тября }\end{array}$ & 4108660 & 1,9 \\
\hline $12-18$ июня & 2587203 & 1,5 & $\begin{array}{c}11-17 \text { сен- } \\
\text { тября }\end{array}$ & 3881581 & 1,7 \\
\hline
\end{tabular}

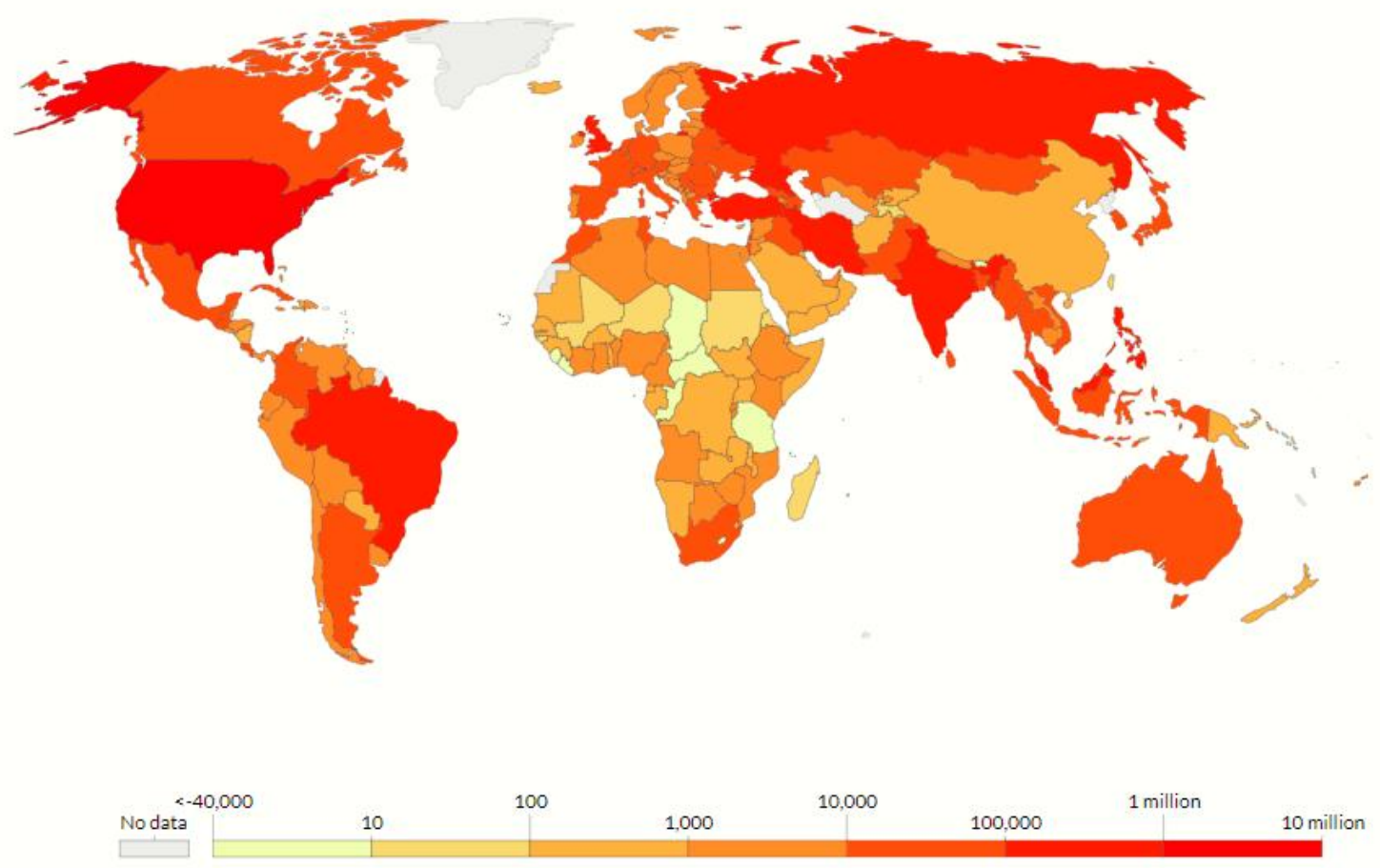

Рисунок 2 - Количество зарегистрированных случаев с 11.09.2021 г. по 17.09.2021 г. 
За последнюю неделю в мире каждый день число новых случаев увеличивалось на 400 - 600 тысяч (таблица 2). 
Таблица 2 - Количество дней, в течение которых зафиксирован прирост в 1 млн новых случаев

\begin{tabular}{|c|c|c|c|c|c|c|c|}
\hline Прирост & $\begin{array}{c}\text { Количе- } \\
\text { ство } \\
\text { дней, по- } \\
\text { надо- } \\
\text { бившихся } \\
\text { для пре- } \\
\text { одоления } \\
\text { отметки } \\
\end{array}$ & Прирост & $\begin{array}{l}\text { Количе- } \\
\text { ство дней }\end{array}$ & Прирост & $\begin{array}{l}\text { Количе- } \\
\text { ство дней }\end{array}$ & Прирост & $\begin{array}{l}\text { Количе- } \\
\text { ство дней }\end{array}$ \\
\hline 0 - 1 млн. & $\begin{array}{l}100 \\
\text { дней }\end{array}$ & $\begin{array}{c}57-58 \\
\text { млн }\end{array}$ & 2 дня & $\begin{array}{c}114-115 \\
\text { млн }\end{array}$ & 3 дня & $\begin{array}{c}171-172 \\
\text { мЛН }\end{array}$ & 2 дня \\
\hline 1 - 2 млн. & 12 дней & $\begin{array}{c}58 \text { - } 59 \\
\text { млн }\end{array}$ & 2 дня & $\begin{array}{c}115 \text { - } 116 \\
\text { млн }\end{array}$ & 3 дня & $\begin{array}{c}172-173 \\
\text { мЛн }\end{array}$ & 3 дня \\
\hline 2 - 3 млн. & 13 дней & $\begin{array}{c}59 \text { - } 60 \\
\text { млн }\end{array}$ & 2 дня & $\begin{array}{c}116-117 \\
\text { млн }\end{array}$ & 3 дня & $\begin{array}{c}173-174 \\
\text { мЛН }\end{array}$ & 3 дня \\
\hline 3 - 4 млн. & 12 дней & $\begin{array}{c}60-61 \\
\text { млн }\end{array}$ & 2 дня & $\begin{array}{c}117-118 \\
\text { млН }\end{array}$ & 2 дня & $\begin{array}{c}174-175 \\
\text { мЛН }\end{array}$ & 2 дня \\
\hline 4 - 5 млн. & 11 дней & $\begin{array}{c}61-62 \\
\text { млн }\end{array}$ & 2 дня & $\begin{array}{c}118-119 \\
\text { млн }\end{array}$ & 2 дня & $\begin{array}{c}175 \text { - } 176 \\
\text { мЛн }\end{array}$ & 3 дня \\
\hline 5 - 6 млн. & 10 дней & $\begin{array}{c}62-63 \\
\text { млн }\end{array}$ & 2 дня & $\begin{array}{c}119-120 \\
\text { млН }\end{array}$ & 3 дня & $\begin{array}{c}176-177 \\
\text { мЛН }\end{array}$ & 3 дня \\
\hline 6 - 7 млн. & 8 дней & $\begin{array}{c}63-64 \\
\text { млн }\end{array}$ & 2 дня & $\begin{array}{c}120-121 \\
\text { млН }\end{array}$ & 2 дня & $\begin{array}{c}177-178 \\
\text { мЛН }\end{array}$ & 2 дня \\
\hline 7 - 8 млн. & 8 дней & $\begin{array}{c}64-65 \\
\text { млн }\end{array}$ & 2 дня & $\begin{array}{c}121-122 \\
\text { млн }\end{array}$ & 2 дня & $\begin{array}{c}178-179 \\
\text { мЛН }\end{array}$ & 3 дня \\
\hline 8 - 9 млн. & 6 дней & $\begin{array}{c}65-66 \\
\text { млн }\end{array}$ & 2 дня & $\begin{array}{c}122-123 \\
\text { млН }\end{array}$ & 2 дня & $\begin{array}{c}179-180 \\
\text { мЛН }\end{array}$ & 3 дня \\
\hline $\begin{array}{l}9 \text { - } 10 \\
\text { млн. }\end{array}$ & 6 дней & $\begin{array}{c}66-67 \\
\text { млн }\end{array}$ & 2 дня & $\begin{array}{c}123-124 \\
\text { млн }\end{array}$ & 2 дня & $\begin{array}{c}180-181 \\
\text { МЛН }\end{array}$ & 3 дня \\
\hline $\begin{array}{c}10 \text { - } 11 \\
\text { млн. }\end{array}$ & 5 дней & $\begin{array}{c}67-68 \\
\text { млн }\end{array}$ & 2 дня & $\begin{array}{c}124-125 \\
\text { млн }\end{array}$ & 2 дня & $\begin{array}{c}181-182 \\
\text { мЛН }\end{array}$ & 3 дня \\
\hline $\begin{array}{l}11-12 \\
\text { млн. }\end{array}$ & 5 дней & $\begin{array}{c}68-69 \\
\text { млн }\end{array}$ & 2 дня & $\begin{array}{c}125 \text { - } 126 \\
\text { млн }\end{array}$ & 2 дня & $\begin{array}{c}182-183 \\
\text { мЛН }\end{array}$ & 3 дня \\
\hline $\begin{array}{l}12-13 \\
\text { млн. }\end{array}$ & 5 дней & $\begin{array}{c}69-70 \\
\text { млН }\end{array}$ & 1 день & $\begin{array}{c}126- \\
127 \mathrm{MлH} \\
\end{array}$ & 1 день & $\begin{array}{c}183-184 \\
\text { МЛН }\end{array}$ & 3 дня \\
\hline $\begin{array}{c}13-14 \\
\text { мЛн. }\end{array}$ & 5 дней & $\begin{array}{c}70 \text { - } 71 \\
\text { млн }\end{array}$ & 2 дня & $\begin{array}{c}127-128 \\
\text { млН }\end{array}$ & 2 дня & $\begin{array}{c}184-185 \\
\text { мЛН }\end{array}$ & 2 дня \\
\hline $\begin{array}{c}14-15 \\
\text { млн. }\end{array}$ & 5 дней & $\begin{array}{c}71-72 \\
\text { млн }\end{array}$ & 1 день & $\begin{array}{c}128-129 \\
\text { млН }\end{array}$ & 2 дня & $\begin{array}{c}185-186 \\
\text { мЛН }\end{array}$ & 2 дня \\
\hline $\begin{array}{c}15-16 \\
\text { МлН }\end{array}$ & 4 дня & $\begin{array}{c}72-73 \\
\text { млн }\end{array}$ & 2 дня & $\begin{array}{c}129-130 \\
\text { млн }\end{array}$ & 1 день & $\begin{array}{c}186-187 \\
\text { мЛН }\end{array}$ & 3 дня \\
\hline $\begin{array}{c}16-17 \\
\text { млн. }\end{array}$ & 4 дня & $\begin{array}{c}73 \text { - } 74 \\
\text { млн }\end{array}$ & 1 день & $\begin{array}{c}130-131 \\
\text { млН }\end{array}$ & 2 дня & $\begin{array}{c}187-188 \\
\text { мЛН }\end{array}$ & 2 дня \\
\hline $\begin{array}{c}17-18 \\
\text { млН }\end{array}$ & 4 дня & $\begin{array}{c}74-75 \\
\text { млн }\end{array}$ & 2 дня & $\begin{array}{c}131-132 \\
\text { млн }\end{array}$ & 2 дня & $\begin{array}{c}188-189 \\
\text { мЛН }\end{array}$ & 2 дня \\
\hline
\end{tabular}




\begin{tabular}{|c|c|c|c|c|c|c|c|}
\hline $\begin{array}{c}18 \text { - } 19 \\
\text { млн. }\end{array}$ & 4 дня & $\begin{array}{c}75 \text { - } 76 \\
\text { мЛн }\end{array}$ & 1 день & $\begin{array}{c}132 \text { - } 133 \\
\text { мЛн }\end{array}$ & 2 дня & $\begin{array}{c}189 \text { - } 190 \\
\text { мЛн }\end{array}$ & 2 дня \\
\hline $\begin{array}{c}19 \text { - } 20 \\
\text { мЛН }\end{array}$ & 4 дня & $\begin{array}{c}76-77 \\
\text { мЛН }\end{array}$ & 2 дня & $\begin{array}{c}133-134 \\
\text { мЛН }\end{array}$ & 1 день & $\begin{array}{c}190-191 \\
\text { Млн }\end{array}$ & 2 дня \\
\hline $\begin{array}{c}20-21 \\
\text { мЛн }\end{array}$ & 4 дня & $\begin{array}{c}77 \text { - } 78 \\
\text { мЛн }\end{array}$ & 2 дня & $\begin{array}{c}134-135 \\
\text { млн }\end{array}$ & 1 день & $\begin{array}{c}191-192 \\
\text { млн }\end{array}$ & 2 дня \\
\hline $\begin{array}{c}21-22 \\
\text { млН }\end{array}$ & 4 дня & $\begin{array}{c}78 \text { - } 79 \\
\text { мЛН }\end{array}$ & 1 день & $\begin{array}{c}135 \text { - } 136 \\
\text { млн } \\
\end{array}$ & 2 дня & $\begin{array}{c}192 \text { - } 193 \\
\text { млн } \\
\end{array}$ & 1 день \\
\hline $\begin{array}{c}22-23 \\
\text { млн }\end{array}$ & 4 дня & $\begin{array}{c}79-80 \\
\text { мЛн }\end{array}$ & 2 дня & $\begin{array}{c}136-137 \\
\text { мЛн }\end{array}$ & 1 день & $\begin{array}{c}193-194 \\
\text { Млн }\end{array}$ & 2 дня \\
\hline $\begin{array}{c}23-24 \\
\text { мЛН }\end{array}$ & 4 дня & $\begin{array}{c}80-81 \\
\text { мЛН }\end{array}$ & 1 день & $\begin{array}{c}137-138 \\
\text { мЛН }\end{array}$ & 1 день & $\begin{array}{c}194-195 \\
\text { млн }\end{array}$ & 2 дня \\
\hline $\begin{array}{c}24-25 \\
\text { мЛН }\end{array}$ & 4 дня & $\begin{array}{c}81-82 \\
\text { мЛН }\end{array}$ & 2 дня & $\begin{array}{c}138-139 \\
\text { мЛН }\end{array}$ & 2 дня & $\begin{array}{c}195 \text { - } 196 \\
\text { млн }\end{array}$ & 2 дня \\
\hline $\begin{array}{c}25-26 \\
\text { мЛН }\end{array}$ & 4 дня & $\begin{array}{c}82-83 \\
\text { млН }\end{array}$ & 1 день & $\begin{array}{c}139-140 \\
\text { мЛН }\end{array}$ & 1 день & $\begin{array}{c}196-197 \\
\text { млн }\end{array}$ & 1 день \\
\hline $\begin{array}{c}26-27 \\
\text { мЛН }\end{array}$ & 4 дня & $\begin{array}{c}83-84 \\
\text { мЛН }\end{array}$ & 2 дня & $\begin{array}{c}140 \text { - } 141 \\
\text { мЛН }\end{array}$ & 1 день & $\begin{array}{c}197-198 \\
\text { мЛН }\end{array}$ & 2 дня \\
\hline $\begin{array}{c}27-28 \\
\text { мЛн }\end{array}$ & 4 дня & $\begin{array}{c}84-85 \\
\text { мЛн }\end{array}$ & 1 день & $\begin{array}{c}141-142 \\
\text { мЛн }\end{array}$ & 2 дня & $\begin{array}{c}198-199 \\
\text { млн }\end{array}$ & 2 дня \\
\hline $\begin{array}{c}28-29 \\
\text { мЛН }\end{array}$ & 4 дня & $\begin{array}{c}85 \text { - } 86 \\
\text { мЛН }\end{array}$ & 2 дня & $\begin{array}{c}142-143 \\
\text { мЛН }\end{array}$ & 1 день & $\begin{array}{c}199-200 \\
\text { млн }\end{array}$ & 2 дня \\
\hline $\begin{array}{c}29-30 \\
\text { мЛН }\end{array}$ & 4 дня & $\begin{array}{c}86-87 \\
\text { мЛН }\end{array}$ & 1 день & $\begin{array}{c}143-144 \\
\text { мЛН }\end{array}$ & 1 день & $\begin{array}{c}200-201 \\
\text { мЛН }\end{array}$ & 2 дня \\
\hline $\begin{array}{c}30-31 \\
\text { мЛН }\end{array}$ & 4 дня & $\begin{array}{c}87-88 \\
\text { мЛН }\end{array}$ & 1 день & $\begin{array}{c}144-145 \\
\text { мЛн }\end{array}$ & 1 день & $\begin{array}{c}201-202 \\
\text { млн }\end{array}$ & 2 дня \\
\hline $\begin{array}{c}31 \text { - } 32 \\
\text { мЛН }\end{array}$ & 4 дня & $\begin{array}{c}88 \text { - } 89 \\
\text { мЛН }\end{array}$ & 1 день & $\begin{array}{c}145 \text { - } 146 \\
\text { млН }\end{array}$ & 1 день & $\begin{array}{c}202-203 \\
\text { млн }\end{array}$ & 1 день \\
\hline $\begin{array}{c}32-33 \\
\text { мЛН }\end{array}$ & 4 дня & $\begin{array}{c}89 \text { - } 90 \\
\text { мЛН }\end{array}$ & 1 день & $\begin{array}{c}146-147 \\
\text { мЛН }\end{array}$ & 2 дня & $\begin{array}{c}204-205 \\
\text { млн }\end{array}$ & 2 дня \\
\hline $\begin{array}{c}33 \text { - } 34 \\
\text { мЛН }\end{array}$ & 4 дня & $\begin{array}{c}90 \text { - } 91 \\
\text { мЛН }\end{array}$ & 2 дня & $\begin{array}{c}147 \text { - } 148 \\
\text { мЛН }\end{array}$ & 1 день & $\begin{array}{c}205-206 \\
\text { млн }\end{array}$ & 2 дня \\
\hline $\begin{array}{c}34 \text { - } 35 \\
\text { мЛН }\end{array}$ & 4 дня & $\begin{array}{c}91 \text { - } 92 \\
\text { мЛН }\end{array}$ & 1 день & $\begin{array}{c}148 \text { - } 149 \\
\text { мЛН }\end{array}$ & 1 день & $\begin{array}{c}206-207 \\
\text { мЛн }\end{array}$ & 2 дня \\
\hline $\begin{array}{c}35-36 \\
\text { млн }\end{array}$ & 4 дня & $\begin{array}{c}92-93 \\
\text { млн }\end{array}$ & 1 день & $\begin{array}{c}149-150 \\
\text { мЛН }\end{array}$ & 1 день & $\begin{array}{c}207-208 \\
\text { млН }\end{array}$ & 2 дня \\
\hline $\begin{array}{c}36-37 \\
\text { мЛН }\end{array}$ & 4 дня & $\begin{array}{c}93 \text { - } 94 \\
\text { мЛН }\end{array}$ & 1 день & $\begin{array}{c}150-151 \\
\text { мЛН }\end{array}$ & 1 день & $\begin{array}{c}208-209 \\
\text { млн }\end{array}$ & 1 день \\
\hline $\begin{array}{c}37-38 \\
\text { мЛН }\end{array}$ & 4 дня & $\begin{array}{c}94 \text { - } 95 \\
\text { мЛН }\end{array}$ & 1 день & $\begin{array}{c}151-152 \\
\text { мЛН }\end{array}$ & 1 день & $\begin{array}{c}209-210 \\
\text { мЛН }\end{array}$ & 1 день \\
\hline $\begin{array}{c}38 \text { - } 39 \\
\text { МЛН }\end{array}$ & 3 дня & $\begin{array}{c}95 \text { - } 96 \\
\text { мЛН }\end{array}$ & 2 дня & $\begin{array}{c}152-153 \\
\text { мЛН }\end{array}$ & 1 день & $\begin{array}{c}210-211 \\
\text { млн }\end{array}$ & 2 дня \\
\hline $\begin{array}{c}39 \text { - } 40 \\
\text { мЛН }\end{array}$ & 3 дня & $\begin{array}{c}96 \text { - } 97 \\
\text { мЛН }\end{array}$ & 1 день & $\begin{array}{c}153-154 \\
\text { мЛН }\end{array}$ & 2 дня & $\begin{array}{c}211-212 \\
\text { млн }\end{array}$ & 2 дня \\
\hline $\begin{array}{c}40-41 \\
\text { МЛН }\end{array}$ & 2 дня & $\begin{array}{c}97 \text { - } 98 \\
\text { мЛН }\end{array}$ & 1 день & $\begin{array}{c}154-155 \\
\text { МЛН }\end{array}$ & 1 день & $\begin{array}{c}212-213 \\
\text { млн }\end{array}$ & 1 день \\
\hline $\begin{array}{c}41-42 \\
\text { млН }\end{array}$ & 2 дня & $\begin{array}{c}98 \text { - } 99 \\
\text { мЛН }\end{array}$ & 2 дня & $\begin{array}{c}155 \text { - } 156 \\
\text { млН }\end{array}$ & 1 день & $\begin{array}{c}213-214 \\
\text { млн }\end{array}$ & 1 день \\
\hline
\end{tabular}




\begin{tabular}{|c|c|c|c|c|c|c|c|}
\hline $\begin{array}{c}42-43 \\
\text { млн }\end{array}$ & 3 дня & $\begin{array}{c}99 \text { - } 100 \\
\text { млн }\end{array}$ & 2 дня & $\begin{array}{c}156-157 \\
\text { мЛн }\end{array}$ & 1 день & $\begin{array}{c}214-215 \\
\text { мЛн }\end{array}$ & 1 день \\
\hline $\begin{array}{c}43 \text { - } 44 \\
\text { млн }\end{array}$ & 2 дня & $\begin{array}{c}100-101 \\
\text { Млн }\end{array}$ & 2 дня & $\begin{array}{c}157-158 \\
\text { млн }\end{array}$ & 2 дня & $\begin{array}{c}215-216 \\
\text { млн }\end{array}$ & 2 дня \\
\hline $\begin{array}{c}44-45 \\
\text { млн }\end{array}$ & 2 дня & $\begin{array}{c}101-102 \\
\text { млн }\end{array}$ & 1 день & $\begin{array}{c}158-159 \\
\text { млн }\end{array}$ & 1 день & $\begin{array}{c}216-217 \\
\text { мЛн }\end{array}$ & 1 день \\
\hline $\begin{array}{c}45-46 \\
\text { млн }\end{array}$ & 2 дня & $\begin{array}{c}102-103 \\
\text { млн }\end{array}$ & 3 дня & $\begin{array}{c}159-160 \\
\text { млн }\end{array}$ & 1 день & $\begin{array}{c}217-218 \\
\text { мЛн }\end{array}$ & 2 дня \\
\hline $\begin{array}{c}46-47 \\
\text { млн }\end{array}$ & 2 дня & $\begin{array}{c}103-104 \\
\text { млН }\end{array}$ & 2 дня & $\begin{array}{c}160-161 \\
\text { млн }\end{array}$ & 1 день & $\begin{array}{c}218-219 \\
\text { млн }\end{array}$ & 1 день \\
\hline $\begin{array}{c}47 \text { - } 48 \\
\text { млн }\end{array}$ & 2 дня & $\begin{array}{c}104-105 \\
\text { МЛН }\end{array}$ & 2 дня & $\begin{array}{c}161-162 \\
\text { млн }\end{array}$ & 2 дня & $\begin{array}{c}219-220 \\
\text { млН }\end{array}$ & 1 день \\
\hline $\begin{array}{c}48 \text { - } 49 \\
\text { млн }\end{array}$ & 2 дня & $\begin{array}{c}105-106 \\
\text { МлН }\end{array}$ & 2 дня & $\begin{array}{c}162-163 \\
\text { млН }\end{array}$ & 2 дня & $\begin{array}{c}220-221 \\
\text { мЛН }\end{array}$ & 2 дня \\
\hline $\begin{array}{c}49 \text { - } 50 \\
\text { млн }\end{array}$ & 2 дня & $\begin{array}{c}106-107 \\
\text { млН }\end{array}$ & 3 дня & $\begin{array}{c}163-164 \\
\text { млн }\end{array}$ & 2 дня & $\begin{array}{c}221-222 \\
\text { млН }\end{array}$ & 2 дня \\
\hline $\begin{array}{c}50-51 \\
\text { млН }\end{array}$ & 2 дня & $\begin{array}{c}107-108 \\
\text { мЛН }\end{array}$ & 2 дня & $\begin{array}{c}164-165 \\
\text { млН }\end{array}$ & 1 день & $\begin{array}{c}222-223 \\
\text { мЛН }\end{array}$ & 2 дня \\
\hline $\begin{array}{c}51-52 \\
\text { млн }\end{array}$ & 2 дня & $\begin{array}{c}108-109 \\
\text { млн }\end{array}$ & 3 дня & $\begin{array}{c}165-166 \\
\text { млн }\end{array}$ & 2 дня & $\begin{array}{c}223-224 \\
\text { млн }\end{array}$ & 2 дня \\
\hline $\begin{array}{c}52-53 \\
\text { млн }\end{array}$ & 2 дня & $\begin{array}{c}109-110 \\
\text { МЛН }\end{array}$ & 3 дня & $\begin{array}{c}166-167 \\
\text { млН }\end{array}$ & 2 дня & $\begin{array}{c}224-225 \\
\text { мЛН }\end{array}$ & 1 день \\
\hline $\begin{array}{c}53-54 \\
\text { млН }\end{array}$ & 2 дня & $\begin{array}{c}110-111 \\
\text { МЛН }\end{array}$ & 2 дня & $\begin{array}{c}167-168 \\
\text { млН }\end{array}$ & 2 дня & $\begin{array}{c}225-226 \\
\text { мЛН }\end{array}$ & 2 дня \\
\hline $\begin{array}{c}54-55 \\
\text { млн }\end{array}$ & 2 дня & $\begin{array}{c}111-112 \\
\text { млн }\end{array}$ & 3 дня & $\begin{array}{c}168-169 \\
\text { млн }\end{array}$ & 2 дня & $\begin{array}{c}226-227 \\
\text { млн }\end{array}$ & 2 дня \\
\hline $\begin{array}{c}55 \text { - } 56 \\
\text { млн }\end{array}$ & 2 дня & $\begin{array}{c}112 \text { - } 113 \\
\text { мЛН }\end{array}$ & 3 дня & $\begin{array}{c}169-170 \\
\text { млн }\end{array}$ & 2 дня & & \\
\hline $\begin{array}{c}56 \text { - } 57 \\
\text { млН }\end{array}$ & 2 дня & $\begin{array}{c}113-114 \\
\text { млН }\end{array}$ & 2 дня & $\begin{array}{c}170-171 \\
\text { млН }\end{array}$ & 2 дня & & \\
\hline
\end{tabular}


В общей структуре заболеваемости за неделю с 11 по 17 сентября 2021 г. наибольшая доля новых случаев по-прежнему приходится на Американский регион (35,7\%, показатель увеличился на 3,8\%). Доля случаев в Европейском регионе за неделю возросла на $0,7 \%$ и составила 30,8\%. Доля ЗападноТихоокеанского региона снизилась на $0,5 \%$ в сравнении с предыдущей неделей $-12,9 \%$. За анализируемый период доля Юго-Восточной Азии снизилась на $2,5 \%$ и составила $10,9 \%$. Доля Восточно-Средиземноморского региона уменьшилась на 1,3\% в сравнении с предыдущей неделей (7,5\%). Наименьший удельный вес новых случаев заболевания приходится на страны Африканского региона $-2,2 \%$, доля несколько снизилась (на $0,2 \%$ ).

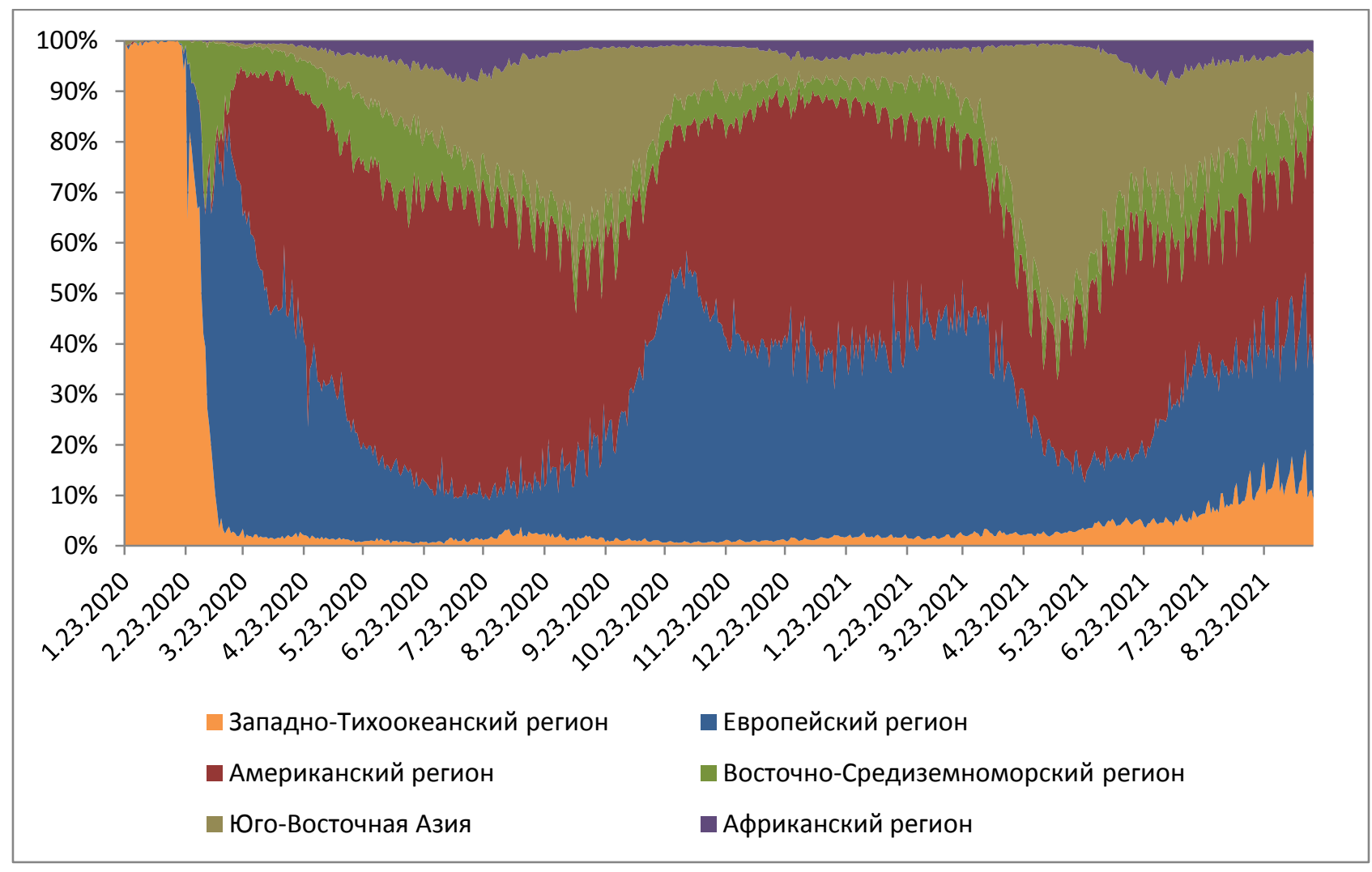

Рисунок 3 - Доля регионов мира в ежедневном приросте случаев заболевания 
Таблица 3 - Средняя доля региона от ежедневного прироста в мире

\begin{tabular}{|c|c|c|c|c|c|c|c|c|c|c|}
\hline \multicolumn{11}{|c|}{ Средняя доля региона от ежедневного прироста в мире, \% } \\
\hline $\begin{array}{c}\text { Регионы } \\
\text { ВО3 }\end{array}$ & $\begin{array}{c}\text { не- } \\
\text { деля } \\
10- \\
16 \\
\text { июля }\end{array}$ & $\begin{array}{c}\text { не- } \\
\text { деля } \\
17- \\
23 \\
\text { июля }\end{array}$ & $\begin{array}{c}\text { не- } \\
\text { деля } \\
24- \\
30 \\
\text { июля }\end{array}$ & $\begin{array}{c}\text { не- } \\
\text { деля } \\
31 \\
\text { июля } \\
-6 \\
\text { авгу- } \\
\text { ста }\end{array}$ & $\begin{array}{c}\text { не- } \\
\text { деля } \\
7- \\
13 \\
\text { авгу- } \\
\text { ста }\end{array}$ & $\begin{array}{c}\text { не- } \\
\text { деля } \\
14- \\
20 \\
\text { авгу- } \\
\text { ста }\end{array}$ & $\begin{array}{c}\text { не- } \\
\text { деля } \\
21- \\
27 \\
\text { авгу- } \\
\text { ста }\end{array}$ & $\begin{array}{c}\text { не- } \\
\text { деля } \\
28 \\
\text { авгу- } \\
\text { ста- } \\
3 \\
\text { сен- } \\
\text { тяб- } \\
\text { ря }\end{array}$ & $\begin{array}{c}\text { не- } \\
\text { деля } \\
4- \\
10 \\
\text { сен- } \\
\text { тяб- } \\
\text { ря }\end{array}$ & $\begin{array}{c}\text { не- } \\
\text { деля } \\
11- \\
17 \\
\text { сен- } \\
\text { тября }\end{array}$ \\
\hline $\begin{array}{c}\text { Западно- } \\
\text { Тихоокеан- } \\
\text { ский регион }\end{array}$ & 5,3 & 6,1 & 7,4 & 8,5 & 9,5 & 11,3 & 12,6 & 13,0 & 13,4 & 12,9 \\
\hline $\begin{array}{c}\text { Европей- } \\
\text { ский регион }\end{array}$ & 26,2 & 30,5 & 27,7 & 26,4 & 27,3 & 27,2 & 28,3 & 28,0 & 30,1 & 30,8 \\
\hline $\begin{array}{l}\text { Американ- } \\
\text { ский регион }\end{array}$ & 27,9 & 26,9 & 28,1 & 30,0 & 30,1 & 31,3 & 32,2 & 33,2 & 31,9 & 35,7 \\
\hline $\begin{array}{c}\text { Восточно- } \\
\text { Средизем- } \\
\text { номорский } \\
\text { регион }\end{array}$ & 10,4 & 9,4 & 11,1 & 11,6 & 11,7 & 11,1 & 10,1 & 9,5 & 8,8 & 7,5 \\
\hline $\begin{array}{c}\text { Юго- } \\
\text { Восточная } \\
\text { Азия } \\
\end{array}$ & 23,8 & 22,0 & 21,2 & 19,5 & 17,6 & 15,6 & 13,5 & 13,5 & 13,4 & 10,9 \\
\hline $\begin{array}{c}\text { Африкан- } \\
\text { ский регион }\end{array}$ & 6,4 & 5,2 & 4,5 & 4,0 & 3,8 & 3,5 & 3,3 & 2,8 & 2,4 & 2,2 \\
\hline
\end{tabular}




\section{Американский регион}

В регионе на анализируемой неделе отмечен рост числа новых случаев заболевания на 6,6\% в сравнении с предыдущей неделей (рисунок 4).

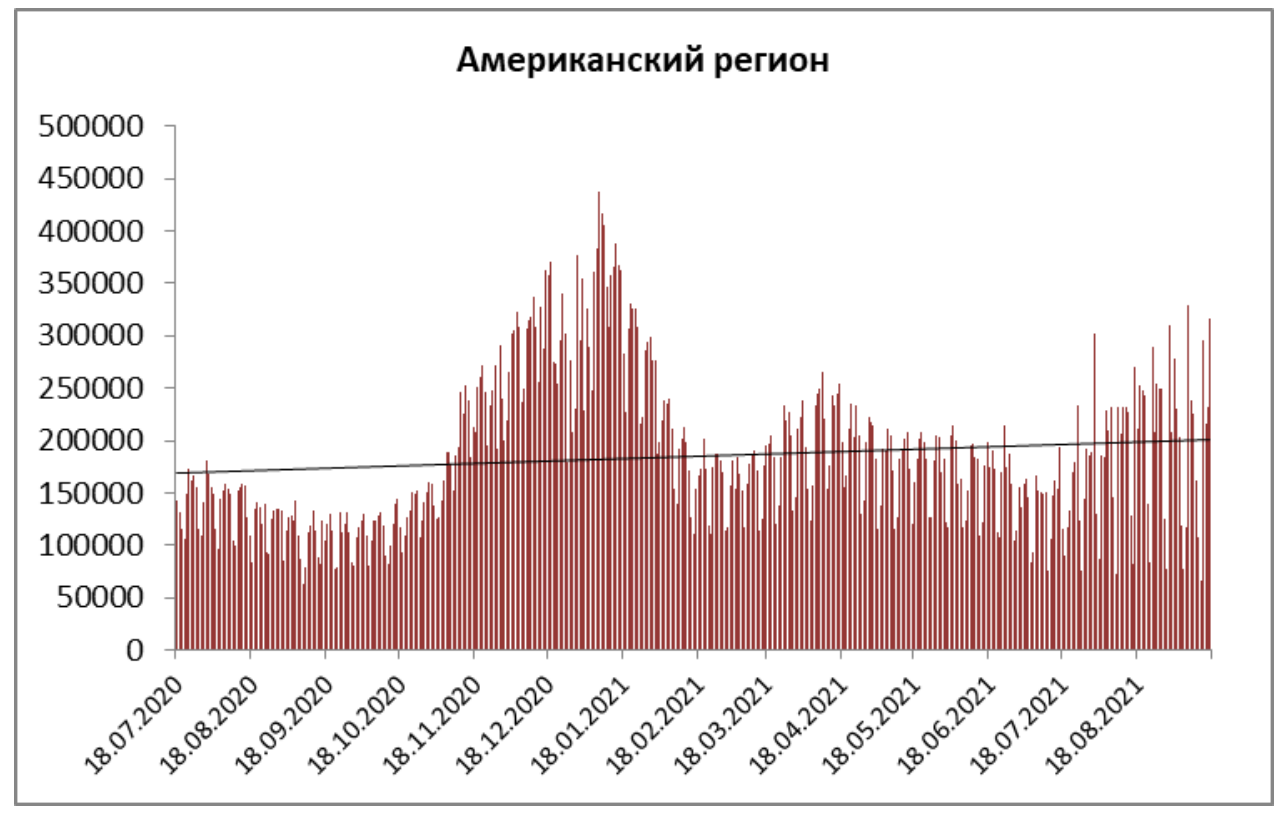

Рисунок 4 - Динамика ежедневного прироста новых случаев в Американском регионе

Количество стран региона, в которых зафиксирован рост числа новых случаев за неделю составило 17, наибольший по сравнению с предыдущей неделей - в Доминике, Гренаде и Суринаме (таблица 4).

Таблица 4 - Страны с максимальным увеличением количества случаев, зарегистрированных за неделю (при сравнении недели с 4 по 10 сентября и недели с 11 по 17 сентября)

\begin{tabular}{|c|c|c|c|c|c|}
\hline \multirow{3}{*}{ Страна } & \multicolumn{4}{|c|}{ Зарегистрировано } & \multirow{3}{*}{ 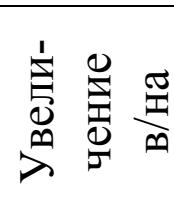 } \\
\hline & \multicolumn{2}{|c|}{ с 4 по 10 сентября } & \multicolumn{2}{|c|}{ с 11 по 17 сентября } & \\
\hline & абс. число & на 1 млн & абс. число & на 1 млн & \\
\hline Доминика & 343 & 4763,9 & 583 & 8097,2 & $70 \%$ \\
\hline Гренада & 931 & 8312,5 & 1514 & 13517,9 & $62,6 \%$ \\
\hline
\end{tabular}




\begin{tabular}{|l|l|l|l|l|l|}
\hline Суринам & 2268 & 3903,6 & 3628 & 6244,4 & $60 \%$ \\
\hline
\end{tabular}

На анализируемой неделе среди стран региона по числу еженедельно выявляемых случаев доминируют Бразилия и США. Удельный вес новых случаев в общей заболеваемости в Американском регионе в этих двух странах на неделе составил $83 \%$ (рисунок 5).

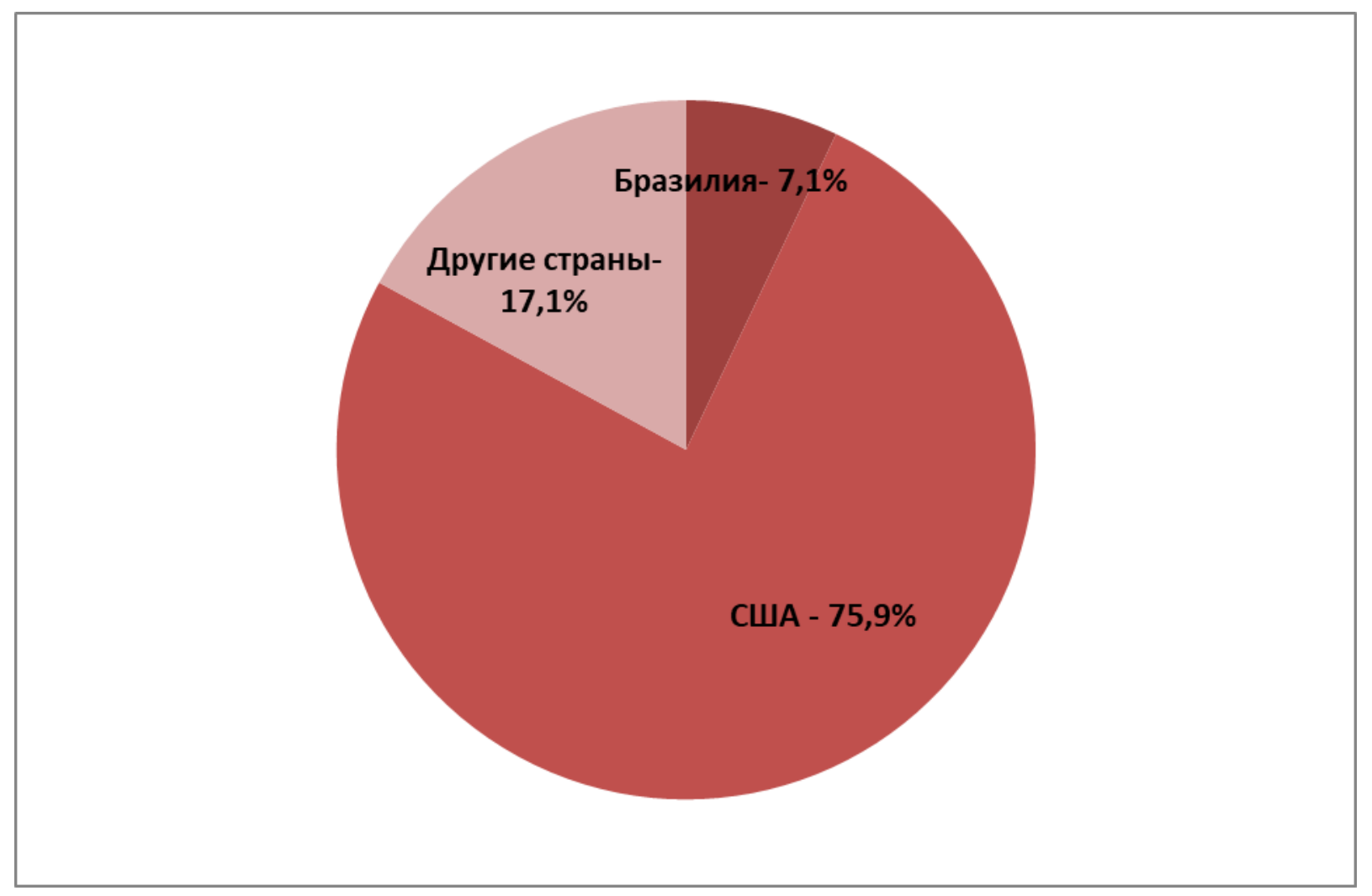

Рисунок 5 - Доля Бразилии, США и других стран в количестве случаев, зарегистрированных за отчетную неделю

Наибольшее число заболевших в регионе на 1 млн населения за последнюю неделю зарегистрировано в Гренаде (13517), Доминике (8097) и Суринаме (6244). Наибольшее число летальных исходов на 1 млн населения за последнюю неделю зарегистрировано в Гренаде (250), Антигуа и Барбуда (82) и Сен-Китс и Невисе (71). 
В настоящее время наблюдается рост заболеваемости в Канаде (рисунок 6). В стране продолжается четвертая волна эпидемии COVID-19. Власти ряда канадских регионов, таких как Британская Колумбия, Квебек, Манитоба и Новая Шотландия, объявили о введении паспортов вакцинации, без которых граждане не смогут посещать рестораны, спортзалы, кинотеатры и различные массовые мероприятия. В Онтарио такие паспорта введут с 22 сентября. Кроме того, во многих регионах потребовали от медицинских работников, полицейских и других категорий граждан пройти обязательную вакцинацию от COVID-19, что вызвало недовольство у определенной части канадского населения.

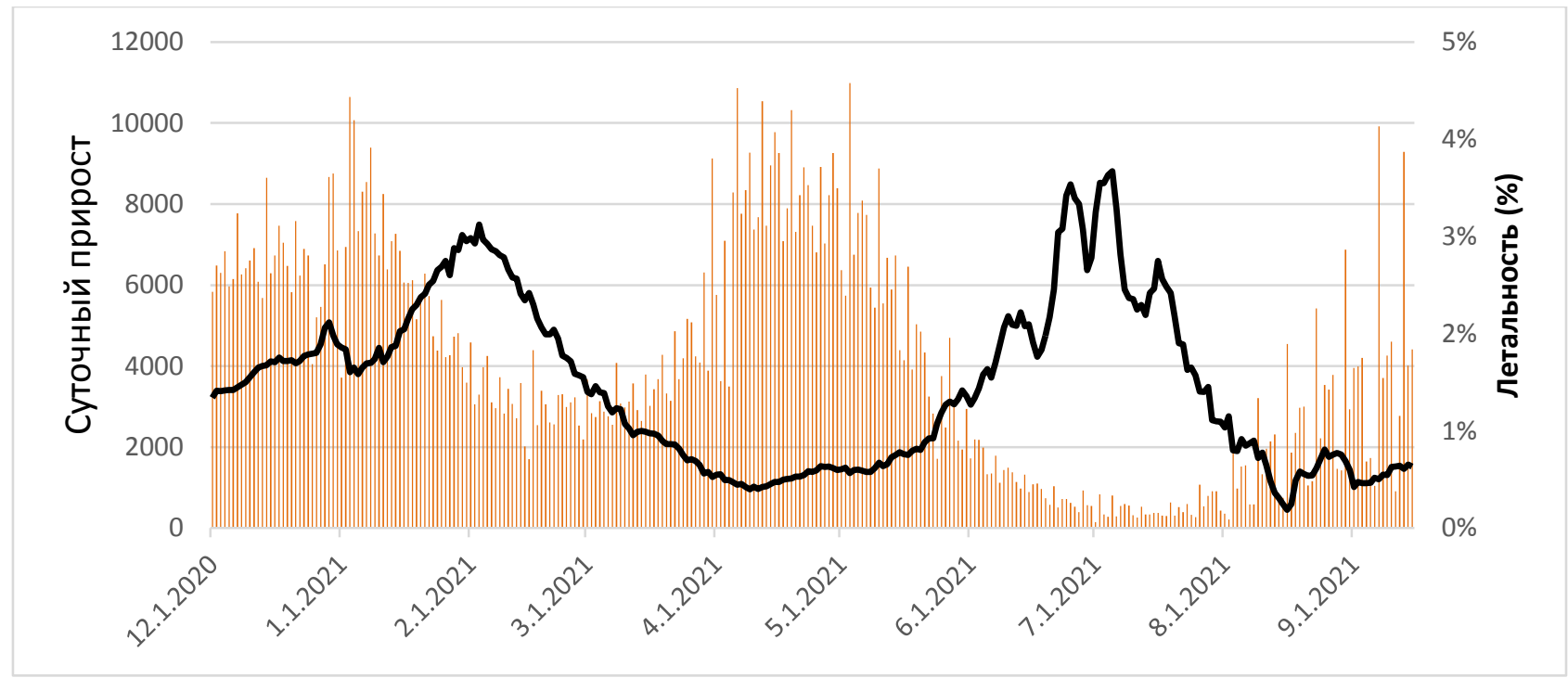

Рисунок 6 - Динамика ежесуточного прироста новых случаев заболевания и летальности в Канаде (как отношения средних показателей прироста смертей и случаев за 7-дневный период)

Неблагопритяная эпидситуация отмечается также в США (рисунок 7). В последнюю неделю в стране в среднем регистрировалось более 152300 новых случаев заражения COVID-19 за сутки. Количество летальных исходов каждый день в течение последней недели составляло более 1800. По данным университета Джонса Хопкинса, от последствий заражения COVID-19 умер почти каж- 
дый 500-й житель США, четверть из них старше 85 лет. В последнее время большинство новых случаев заражения в стране вызвано штаммом "дельта".

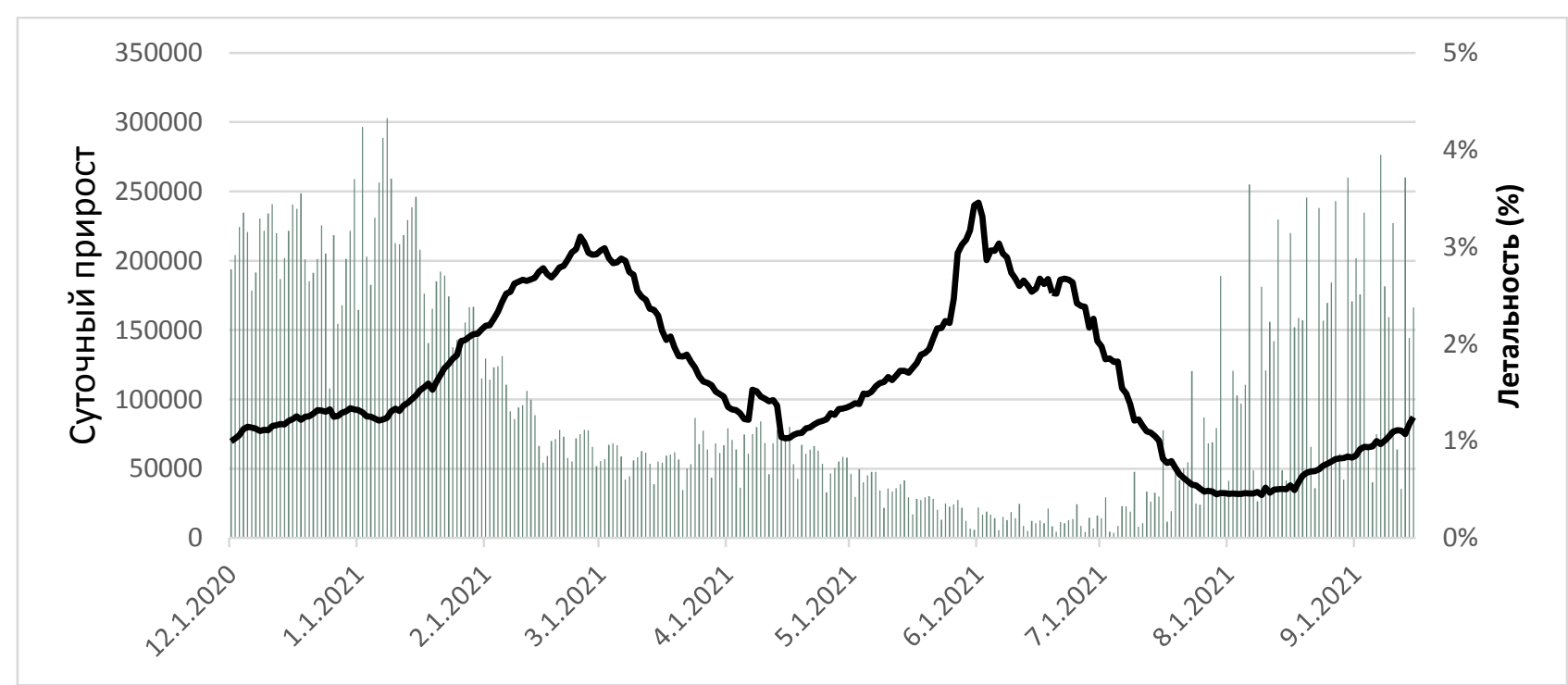

Рисунок 7 - Динамика ежесуточного прироста новых случаев в США (как отношения средних показателей прироста смертей и случаев за 7-дневный период)

\section{Европейский регион}

В Европейском регионе на анализируемой неделе отмечено снижение числа новых случаев заражения на $3,7 \%$ в сравнении с предыдущей неделей (рисунок 8). 


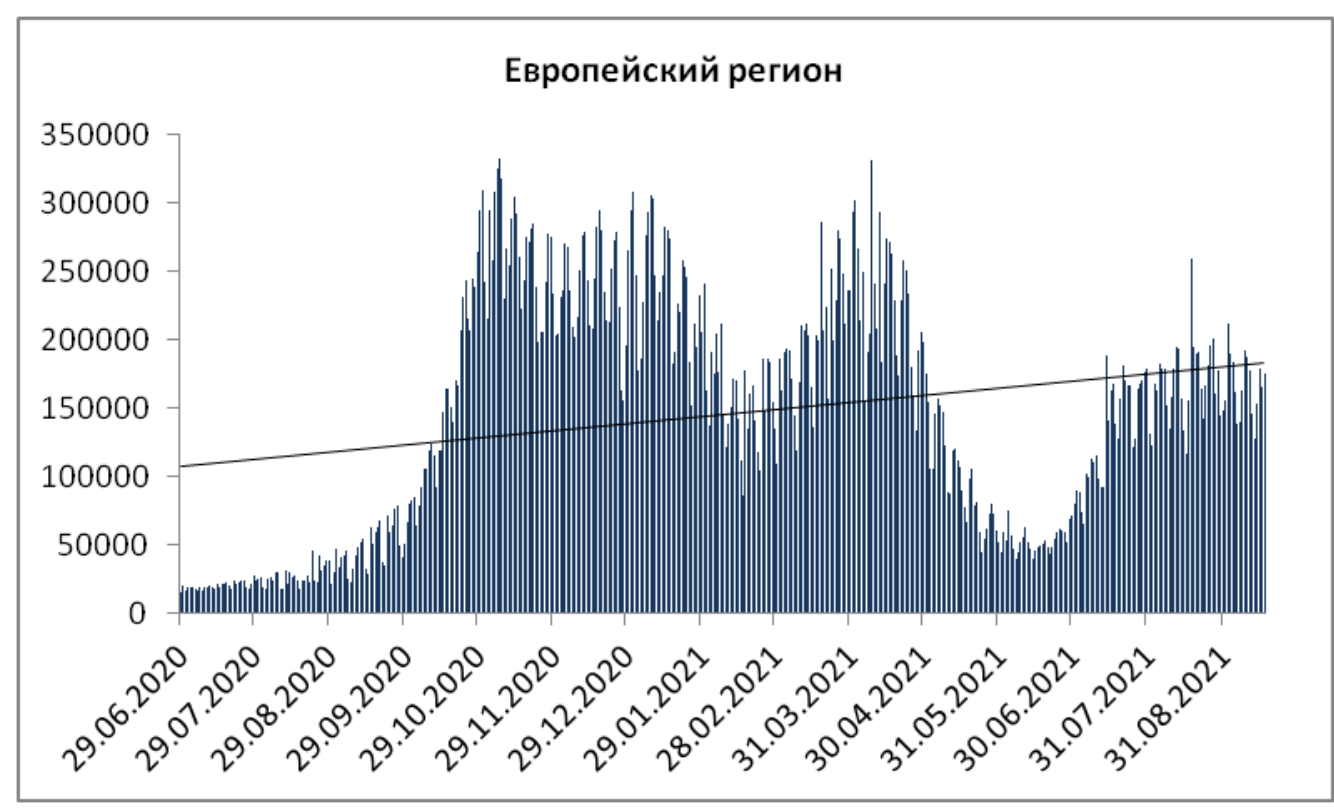

Рисунок 8 - Динамика ежедневного прироста новых случаев в Европейском регионе

Рост заболеваемости за неделю отмечен в 29 из 56 стран региона, наибольший - в Румынии, Украине, Молдавии, Словении (таблица 5).

Таблица 5 - Страны с максимальным увеличением количества случаев, зарегистрированных за неделю (при сравнении недели с 4 по 10 сентября и недели с 11 по 17 сентября)

\begin{tabular}{|c|c|c|c|c|c|}
\hline \multirow{3}{*}{ Страна } & \multicolumn{4}{|c|}{ Зарегистрировано } & \multirow{3}{*}{ 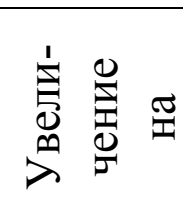 } \\
\hline & \multicolumn{2}{|c|}{ с 4 по 10 сентября } & \multicolumn{2}{|c|}{ с 11 по 17 сентября } & \\
\hline & абс. число & на 1 млн & абс. число & на 1 млн & \\
\hline Румыния & 11703 & 603,2 & 21646 & 1115,7 & $85 \%$ \\
\hline Украина & 16091 & 387,7 & 24601 & 592,8 & $52,9 \%$ \\
\hline Молдавия & 4164 & 1174,1 & 6087 & 1716,3 & $46,2 \%$ \\
\hline Словения & 4893 & 2313,3 & 7015 & 3316,6 & $43,4 \%$ \\
\hline
\end{tabular}

Наибольшее число инфицированных на 1 млн населения в регионе за неделю зафиксировано в Черногории (6967), Израиле (6838) и Сербии (5183). 
Наибольшее число летальных исходов на 1 млн населения за последнюю неделю отмечено в Грузии $(95,3)$, Северной Македонии $(88,1)$ и Болгарии $(70,3)$.

В настоящее время рост заболеваемости COVID-19 наблюдается на Украине (рисунок 9). Больше всего новых случаев заболевания фиксируют во Львовской, Харьковской, Днепропетровской, Киевской и Одесской областях. Кабинет министров Украины внедрил "желтые" и "зеленые" COVID-паспорта для украинцев, содержащие информацию о полной или частичной вакцинации и согласно которым для всех привитых будут действовать привилегии.

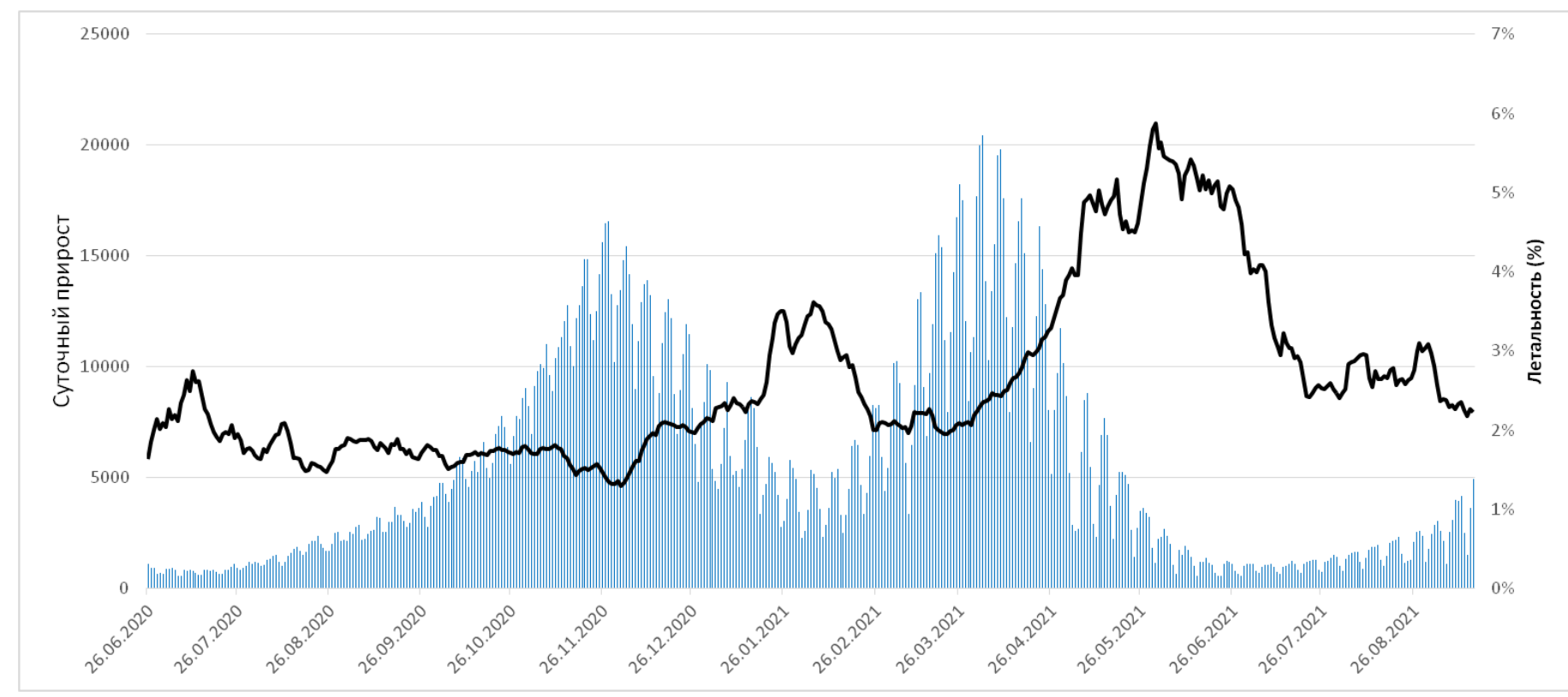

Рисунок 9 - Динамика ежесуточного прироста новых случаев заболевания и летальности на Украине (как отношения средних показателей прироста смертей и случаев за 7-дневный период)

Рост заболеваемости в настоящее время регистрируется также в Сербии (рисунок 10). В Сербии вакцинированы первой дозой вакцины 2821060 человек, что составляет около 52,2\% населения, ревакцинированных $-50,1 \%$, третью дозу получили около 6\%. Изначально Сербия лидировала по темпам вак- 
цинации в Европе, однако «безответственный» (со слов председателя кабмина страны) подход населения привёл к снижению показателей.

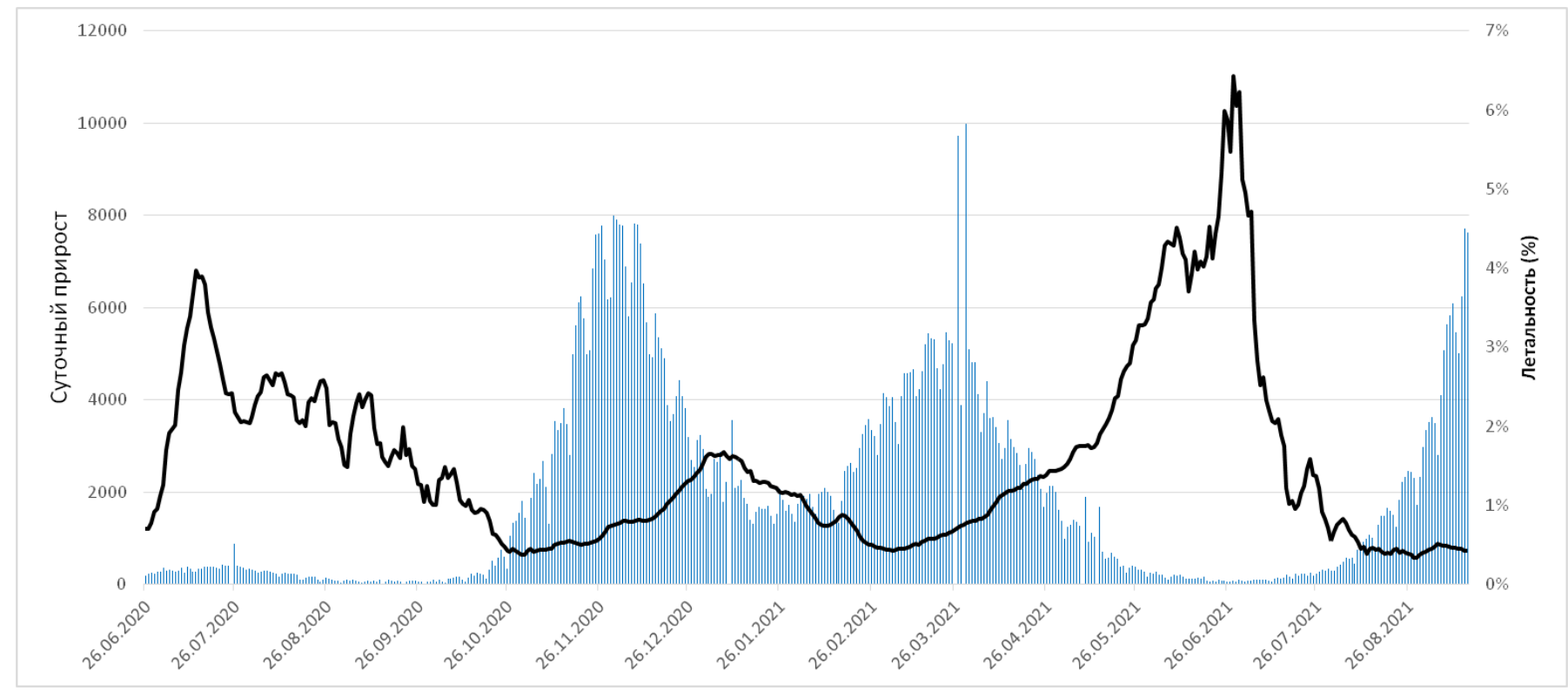

Рисунок 10 - Динамика ежесуточного прироста новых случаев заболевания и летальности в Сербии (как отношения средних показателей прироста смертей и случаев за 7-дневный период)

Доля выявленных случаев в странах СНГ от всех зарегистрированных в Европейском регионе составила 19,9\% - некоторое увеличение по сравнению с прошлой неделей (рисунок 11). 


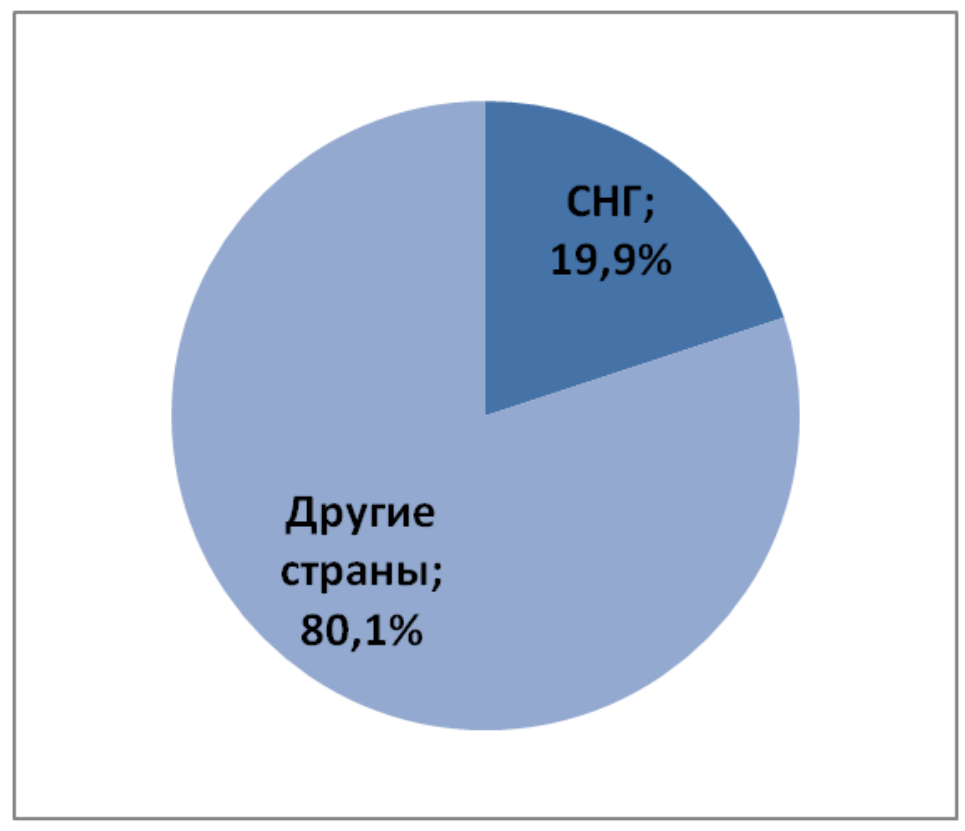

Рисунок 11 - Доля стран СНГ и других стран в количестве случаев, зарегистрированных за отчетную неделю в Европейском регионе

\section{Западно-Тихоокеанский регион}

На анализируемой неделе в Западно-Тихоокеанском регионе отмечено снижение заболеваемости на $10,8 \%$ в сравнении с прошлой неделей (рисунок 12).

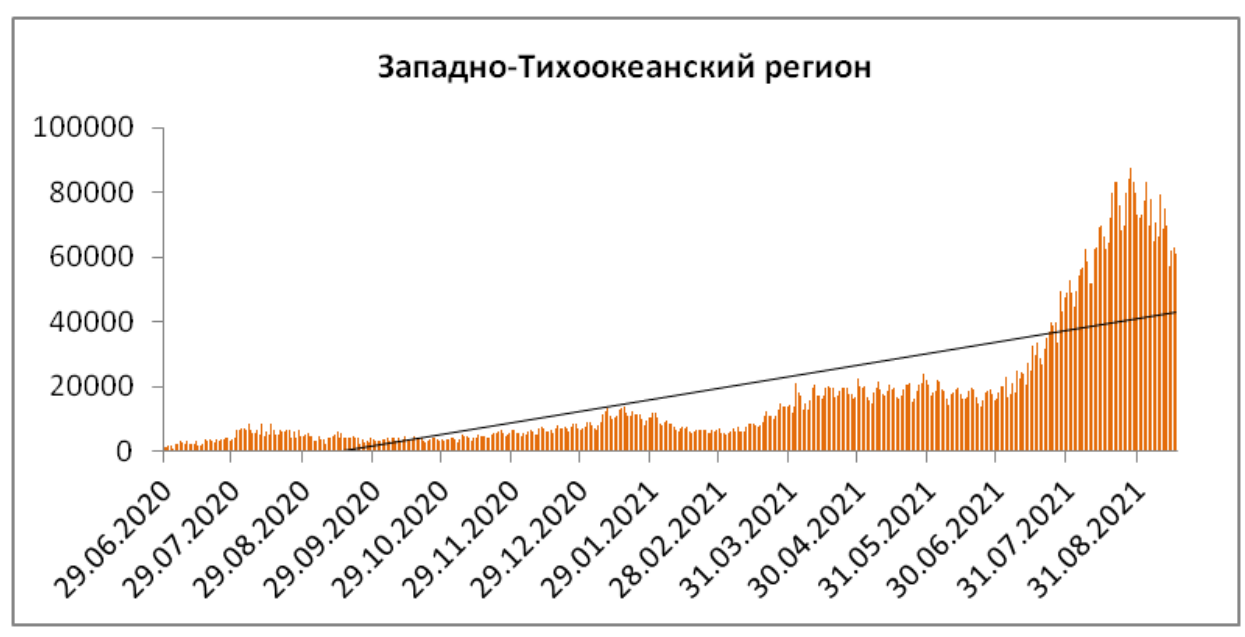

Рисунок 12 - Динамика ежедневного прироста новых случаев в Западно-Тихоокеанском регионе 
В 8 странах региона зафиксирован рост числа новых случаев за неделю, наибольший - в Сингапуре и Камбодже (таблица 6).

Таблица 6 - Страны с максимальным увеличением количества случаев, зарегистрированных за неделю (при сравнении недели с 4 по 10 сентября и недели с 11 по 17 сентября)

\begin{tabular}{|c|c|c|c|c|c|}
\hline \multirow{2}{*}{ Страна } & \multicolumn{4}{|c|}{ Зарегистрировано } & \multirow{2}{*}{} \\
\cline { 2 - 5 } & с 4 по 10 сентября & с 11 по 17 сентября & \multirow{2}{*}{} \\
\cline { 2 - 5 } & абс. число & на 1 млн & абс. число & на 1 млн & \multirow{2}{*}{ Си } \\
\hline Сингапур & 2048 & 359,1 & 4809 & 843,2 & \multirow{2}{*}{ В 2,3 } \\
\hline Камбоджа & 3598 & 235,3 & 4612 & 301,7 & $28,2 \%$ \\
\hline
\end{tabular}

На Малайзию и Филиппины приходится 59,7\% от всех выявленных случаев за неделю в Западно-Тихоокеанском регионе (рисунок 13).

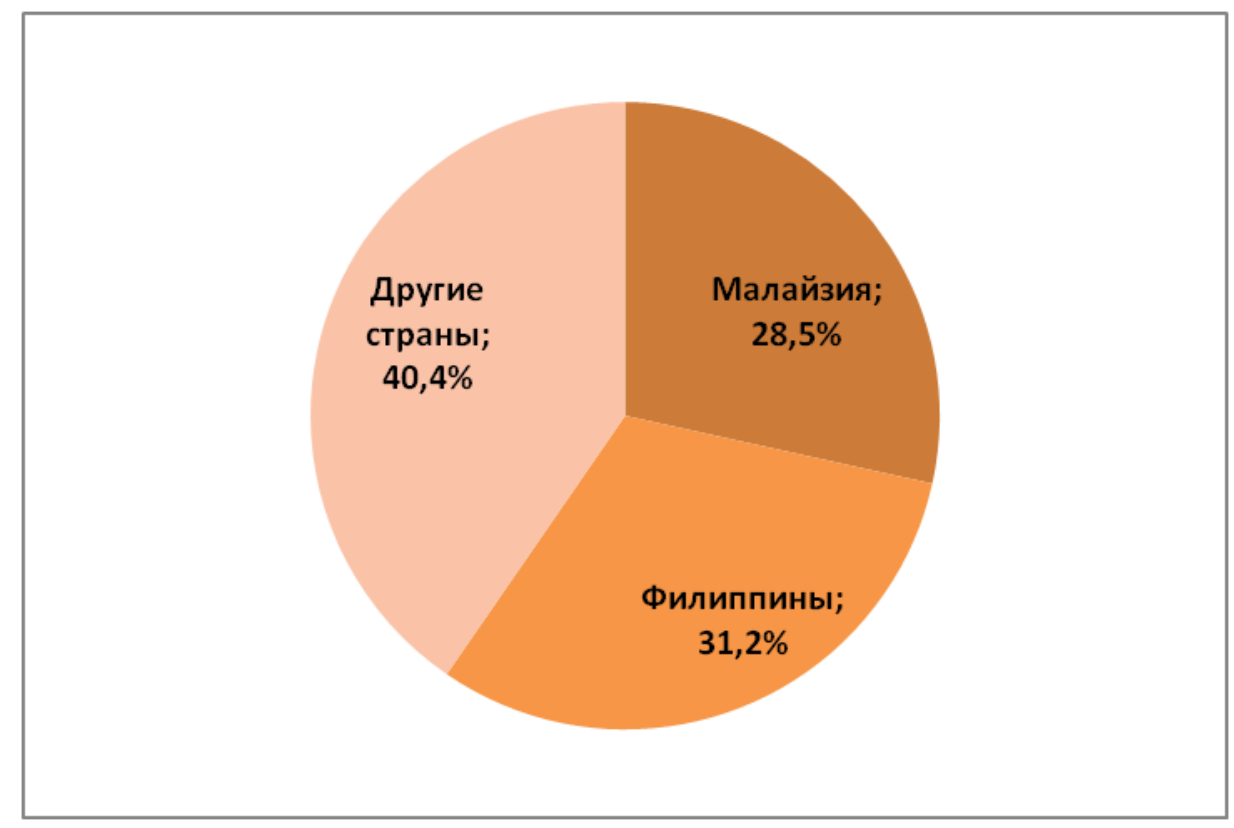

Рисунок 13 - Доля Филиппин, Малайзии и других стран в количестве случаев, зарегистрированных за отчетную неделю. 
В регионе наибольшее число новых случаев заражения на 1 млн населения за неделю зарегистрировано в Монголии (5738) и Малайзии (3931). Наибольшее число летальных исходов на 1 млн населения зафиксировано в Малайзии $(87)$ и Монголии $(24,4)$.

Во Австралии в настоящее время наблюдается значительный рост заболеваемости COVID-19 (рисунок 14). На Австралийской столичной территории, в которую входит и город Канберра, еще как минимум на месяц продлили режим карантина. Главный санитарный врач столичной территории объяснила, что режим карантина продлили прежде всего из-за того, что некоторые диагностируемые случаи COVID-19 не получается связать с существующими вспышками инфекции.

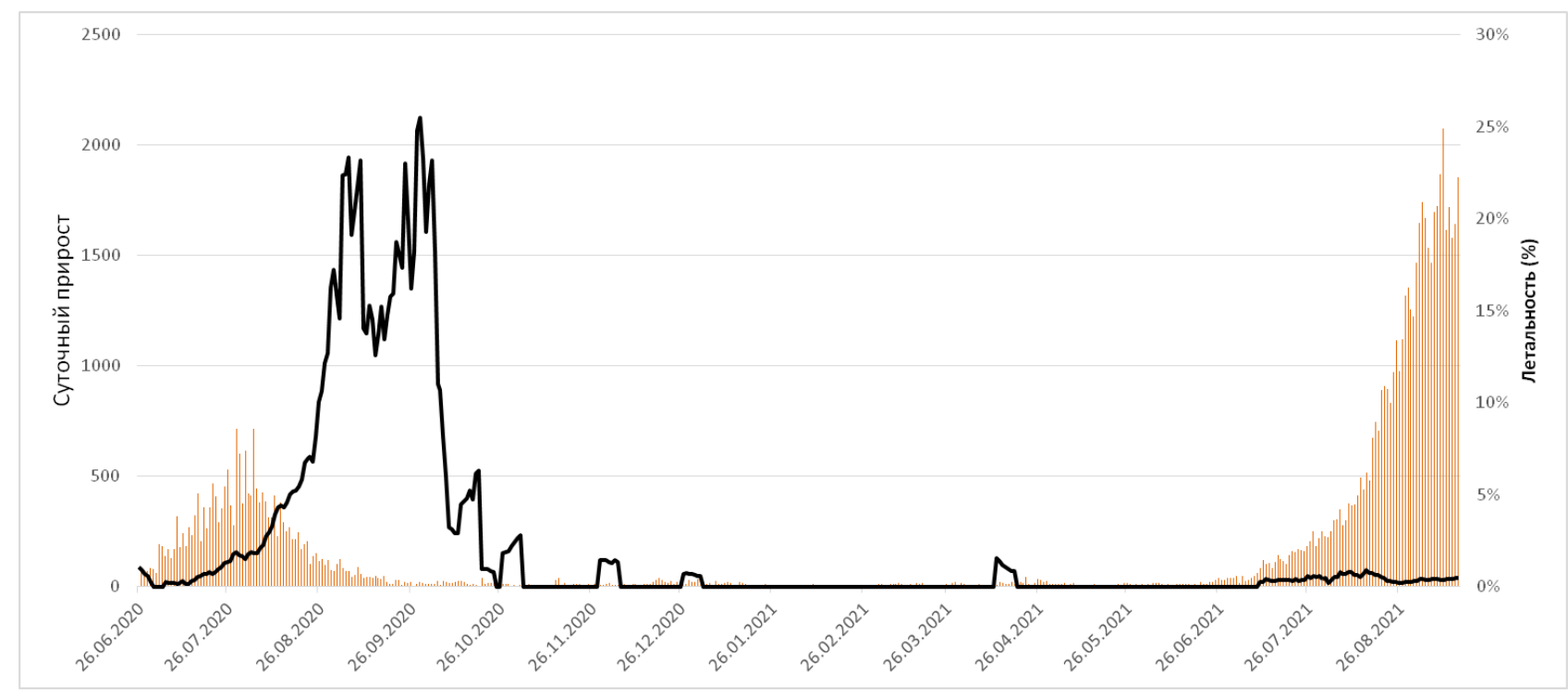

Рисунок 14 - Динамика ежесуточного прироста новых случаев и летальности в Австралии (как отношения средних показателей прироста смертей и случаев за 7-дневный период) 


\section{Восточно-Средиземноморский регион}

В регионе на анализируемой неделе наблюдается снижение числа новых случаев заболевания на 20,3\% в сравнении с прошлой неделей (рисунок 15).

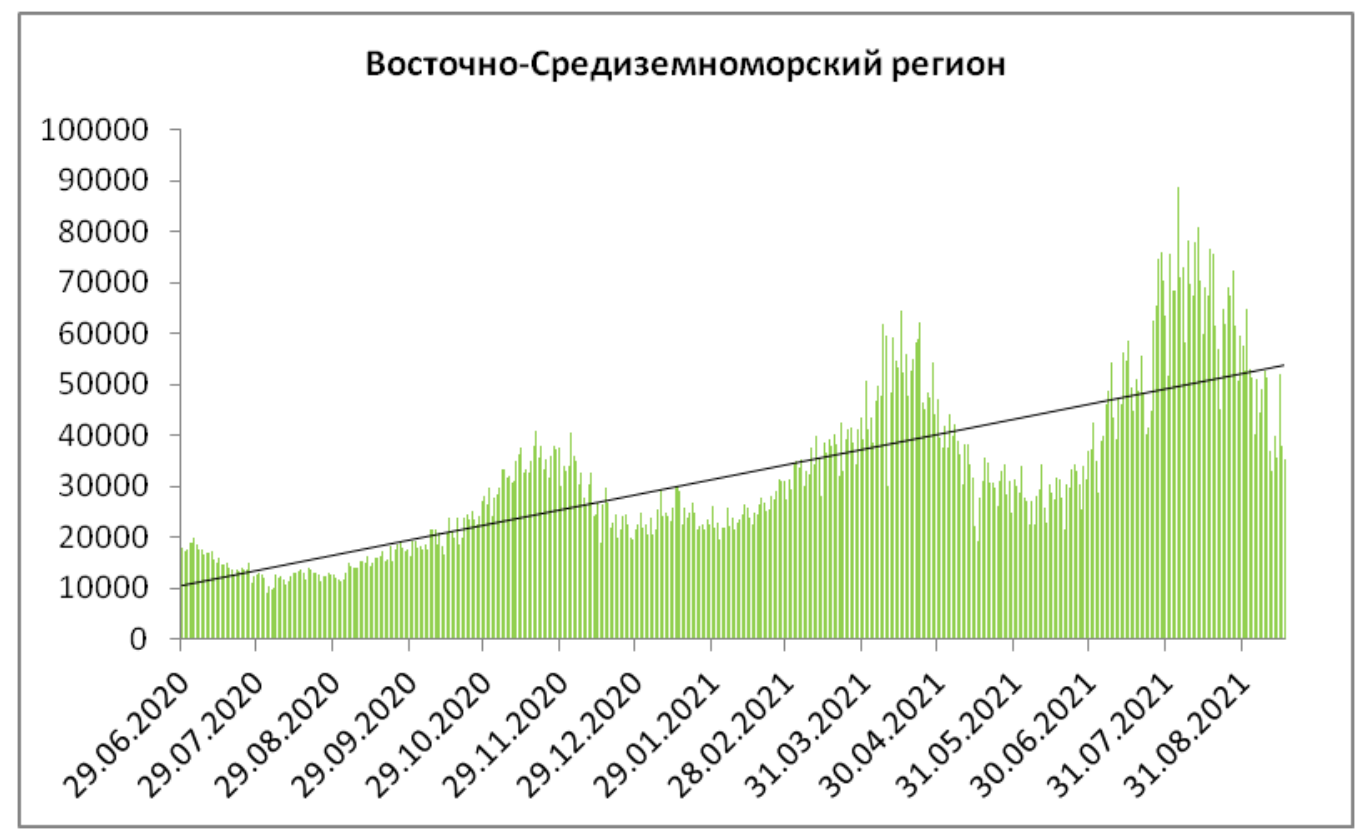

Рисунок 15 - Динамика ежедневного прироста новых случаев в ВосточноСредиземноморском регионе

За неделю в 10 из 22 стран региона отмечен рост числа новых случаев. Максимальное увеличение недельного прироста зафиксировано в Тунисе и Египте (таблица 7).

Таблица 7 - Страны с максимальным увеличением количества случаев, зарегистрированных за неделю (при сравнении недели с 4 по 10 сентября и недели с 11 по 17 сентября) 


\begin{tabular}{|c|c|c|c|c|c|}
\hline \multirow{2}{*}{ Страна } & \multicolumn{4}{|c|}{ Зарегистрировано } & \multirow{2}{*}{} \\
\cline { 2 - 5 } & \multicolumn{2}{|c|}{ с 4 по 10 сентября } & \multicolumn{2}{c|}{ с 11 по 17 сентября } & \\
\cline { 2 - 5 } & абс. число & на 1 млн & абс. число & на 1 млн & \multirow{2}{*}{ Тунис } \\
\hline Египет & 12023 & 1025,7 & 17347 & 1479,9 & $44,3 \%$ \\
\hline
\end{tabular}

На Иран приходится 51,9\% от всех выявленных случаев за неделю с 11 по 17 сентября в Восточно-Средиземноморском регионе (рисунок 16).

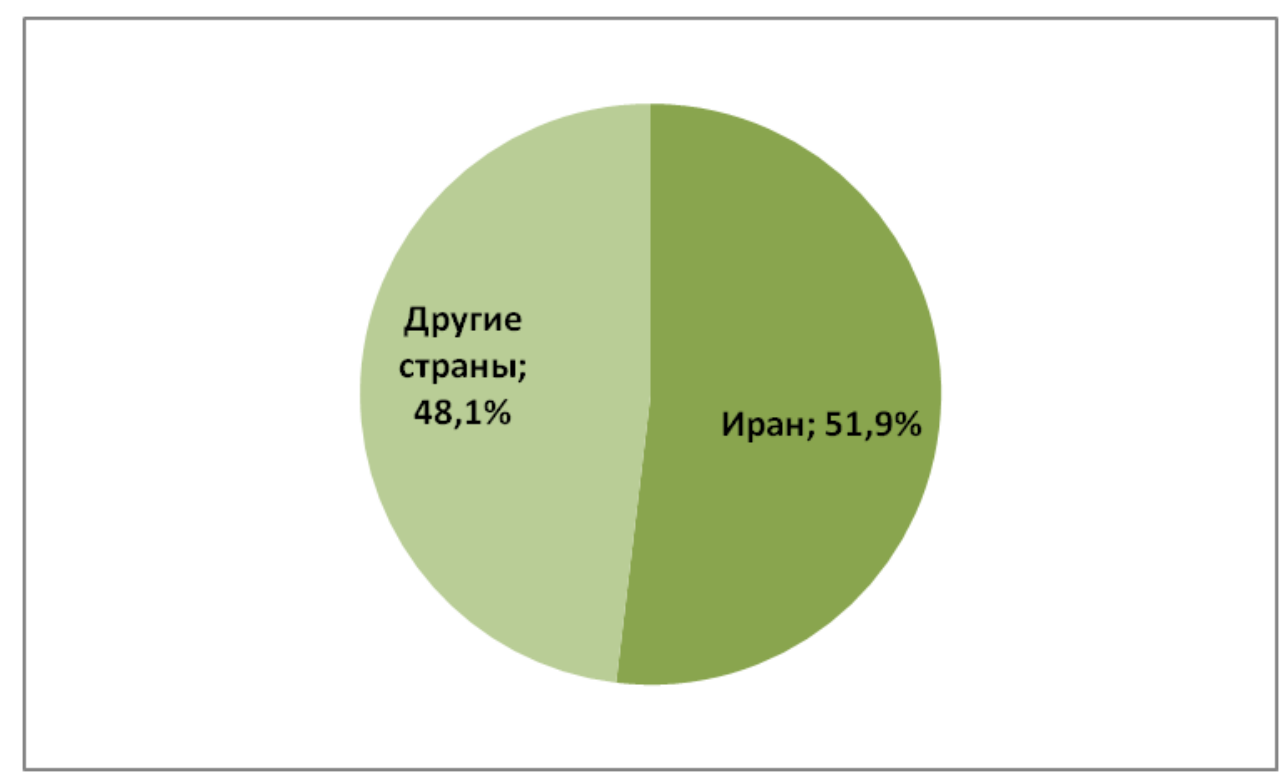

Рисунок 16 - Удельный вес Ирана и других стран в структуре случаев в Восточно-Средиземноморском регионе

Наибольшее число заболевших на 1 млн населения за последнюю неделю зарегистрировано в Палестине (3171) и Иране (1658). Наибольшее число летальных исходов на 1 млн населения за последнюю неделю зарегистрировано в Иране (37) и Тунисе (29). 
В Египте в настоящее время продолжается рост заболеваемости COVID19. Власти страны решили оплачивать медицинские расходы иностранным туристам, заразившимся коронавирусом по прибытии в страну или во время отдыха, сообщил министр туризма и древностей. Въезд в Египет возможен с сертификатом о полной вакцинации (на английском языке), содержащим QR-код, привем отправиться в путешествие можно через 14 дней после получения второго компонента вакцины. Либо турист может предоставить ПЦР-тест, сделанный не ранее 72 часов до вылета в Египет.

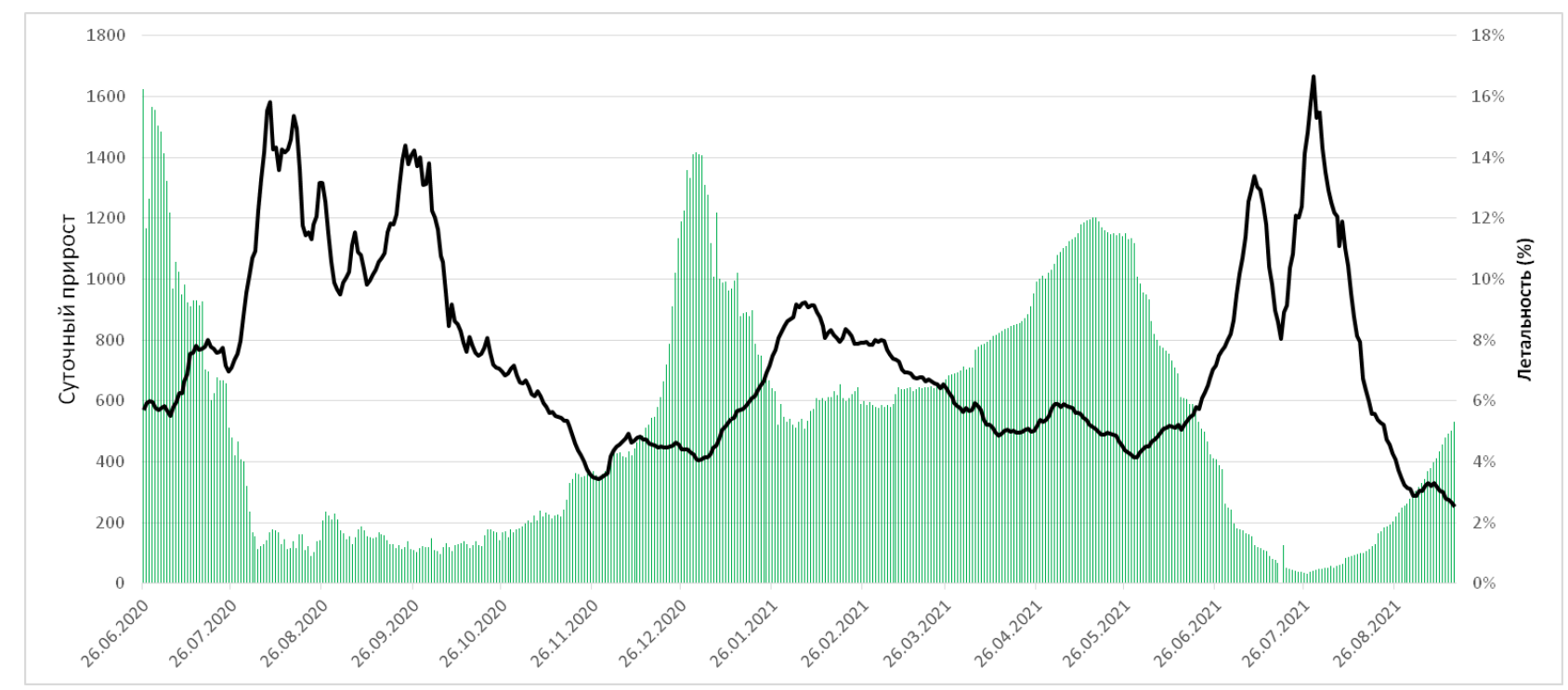

Рисунок 17 - Динамика ежесуточного прироста новых случаев заболевания и летальности в Египте (как отношения средних показателей прироста смертей и случаев за 7-дневный период). 


\section{Юго-Восточная Азия}

В регионе на анализируемой неделе наблюдается снижение числа новых случаев на 23,3\% в сравнении с прошлой неделей (рисунок 18).

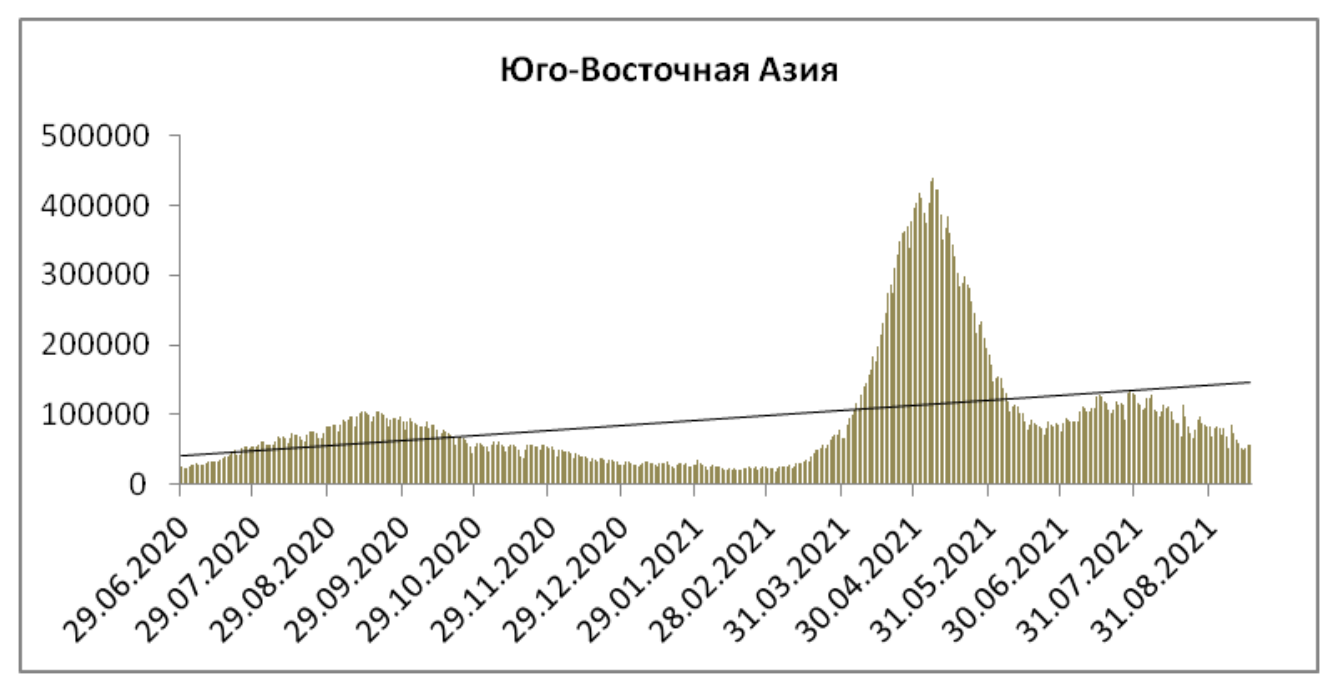

Рисунок 18 - Динамика ежедневного прироста новых случаев в Юго-Восточной Азии

Ни в одной из стран региона не зарегистрировано увеличения прироста по сравнению с прошлой неделей.

На Индию и Таиланд приходится 77,8\% от всех выявленных за неделю случаев в Юго-Восточной Азии в период с 11 по 17 сентября (рисунок 19). 


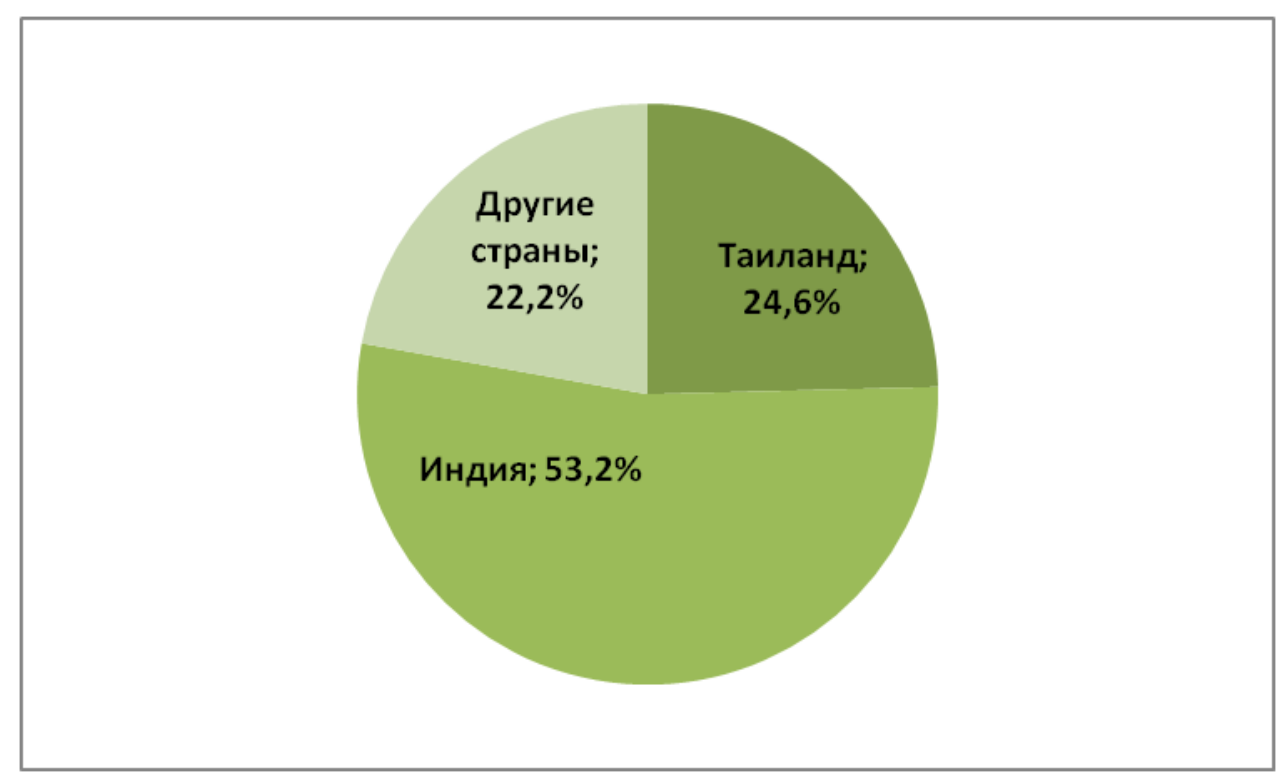

Рисунок 19 - Доля Индии, Таиланда и других стран региона в количестве случаев, зарегистрированных за отчетную неделю

Наибольшее число заболевших на 1 млн населения за последнюю неделю зарегистрировано в Таиланде (1439) и на Мальдивах (1407). Наибольшее число летальных исходов на 1 млн населения за последнюю неделю в регионе зарегистрировано в Шри-Ланке (44) и Таиланде (18).

Продолжают регистрироваться высокие показатели заболеваемости COVID-19 в Таиланде (рис. 20). Тем не менее, с середины августа наметилась устойчивая тенденция к снижению числа ежедневно выявляемых случаев. Таиланд планирует с 1 октября открыть для иностранных туристов ряд регионов, в числе которых - Бангкок, Паттайя, Хуахин и Чиангмай. Ранее в рамках этой же программы открылись такие направления, как Пхукет и три острова провинции Сураттхани - Самуи, Пхан Нга и Тао. При въезде нужно представить сертификат о вакцинации и ПЦР-тест, сделанный не ранее чем за 72 часа до поездки. Также туристы должны сдать еще два или три теста в зависимости от продолжительности поездки. Детям в возрасте до 18 лет нужно представить только тест. 


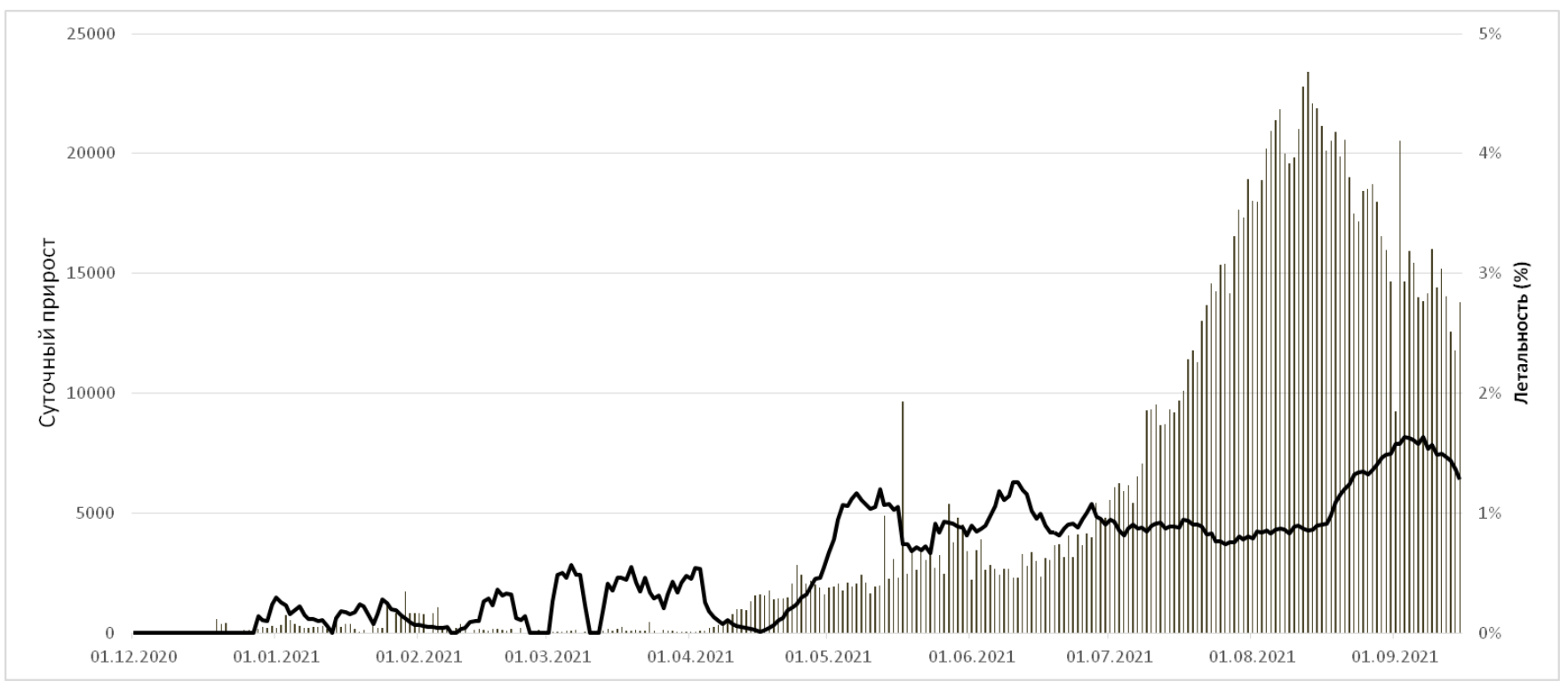

Рисунок 20 - Динамика ежесуточного прироста новых случаев заболевания и летальности в Таиланде (как отношения средних показателей прироста смертей и случаев за 7-дневный период) 


\section{Африканский регион}

В регионе на анализируемой неделе наблюдается снижение числа новых случаев заболевания на 18,4\% в сравнении с прошлой неделей (рисунок 21).

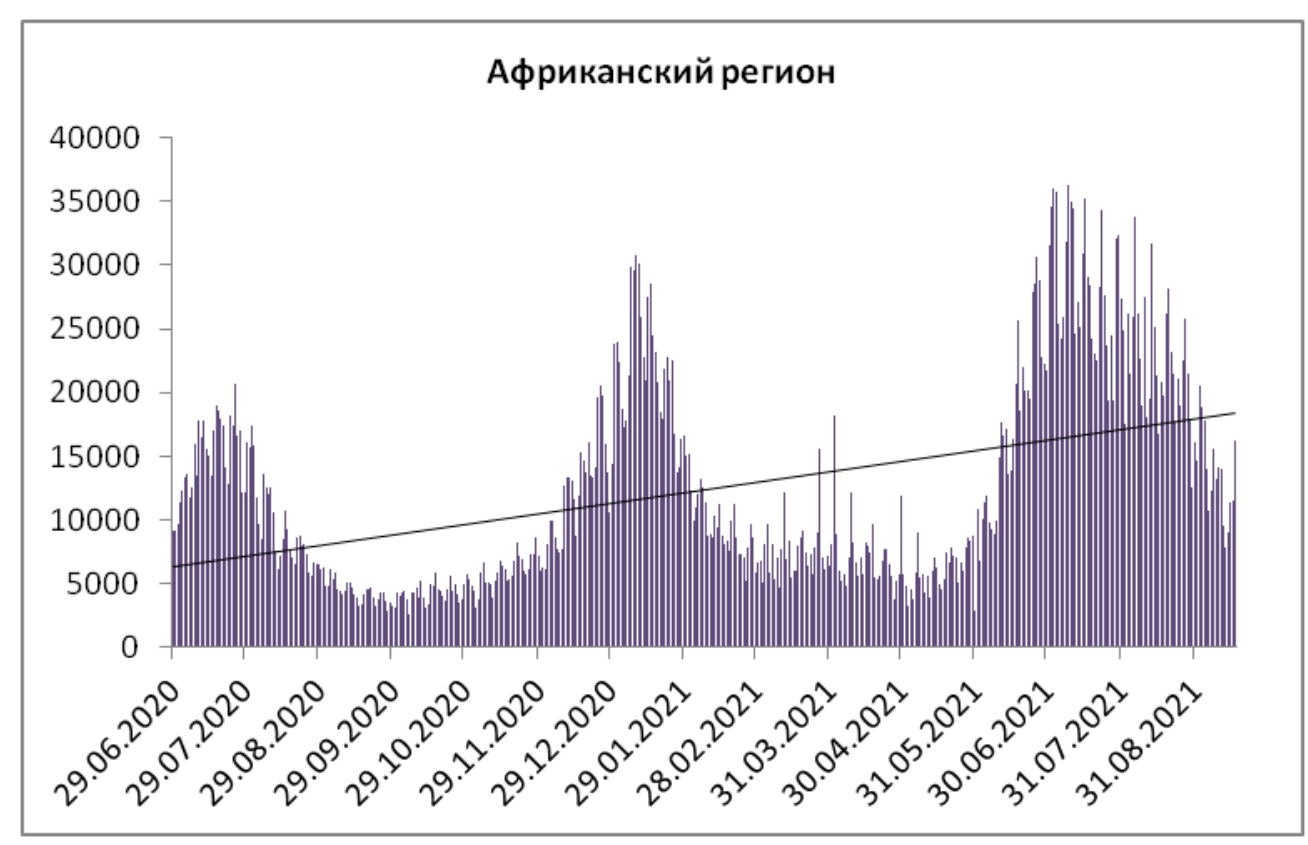

Рисунок 21 - Динамика ежедневного прироста новых случаев в Африканском регионе

В 13 из 48 стран Африканского региона зарегистрирован рост числа новых случаев. Максимальное увеличение еженедельного прироста новых случаев по сравнению с предшествующей неделей демонстрируют Габон и Ботсвана (таблица 9).

Таблица 9 - Страны с максимальным увеличением количества случаев, зарегистрированных за неделю (при сравнении недели с 4 по 10 сентября и недели с 11 по 17 сентября). 


\begin{tabular}{|c|c|c|c|c|c|}
\hline \multirow{2}{*}{ Страна } & \multicolumn{4}{|c|}{ Зарегистрировано } & \multirow{2}{*}{ Увеличе- } \\
\cline { 2 - 5 } & \multicolumn{2}{|c|}{ с 4 по 10 сентября } & \multicolumn{2}{|c|}{ с 11 по 17 сентября } & \begin{tabular}{c} 
ние в/на \\
\cline { 2 - 5 }
\end{tabular} \\
\cline { 2 - 5 } Ббс. число & на 1 млн & $\begin{array}{c}\text { абс. } \\
\text { число }\end{array}$ & на 1 млн & \\
\hline Ботсвана & 4348 & 1887,2 & 8587 & 3727,0 & \multirow{2}{*}{ в 2 раза } \\
\hline Габон & 491 & 226,0 & 912 & 419,7 & $86 \%$ \\
\hline
\end{tabular}

На ЮАР приходится 38,1\% от всех выявленных за неделю случаев в Африканском регионе в период с 11 по 17 сентября (рисунок 22).

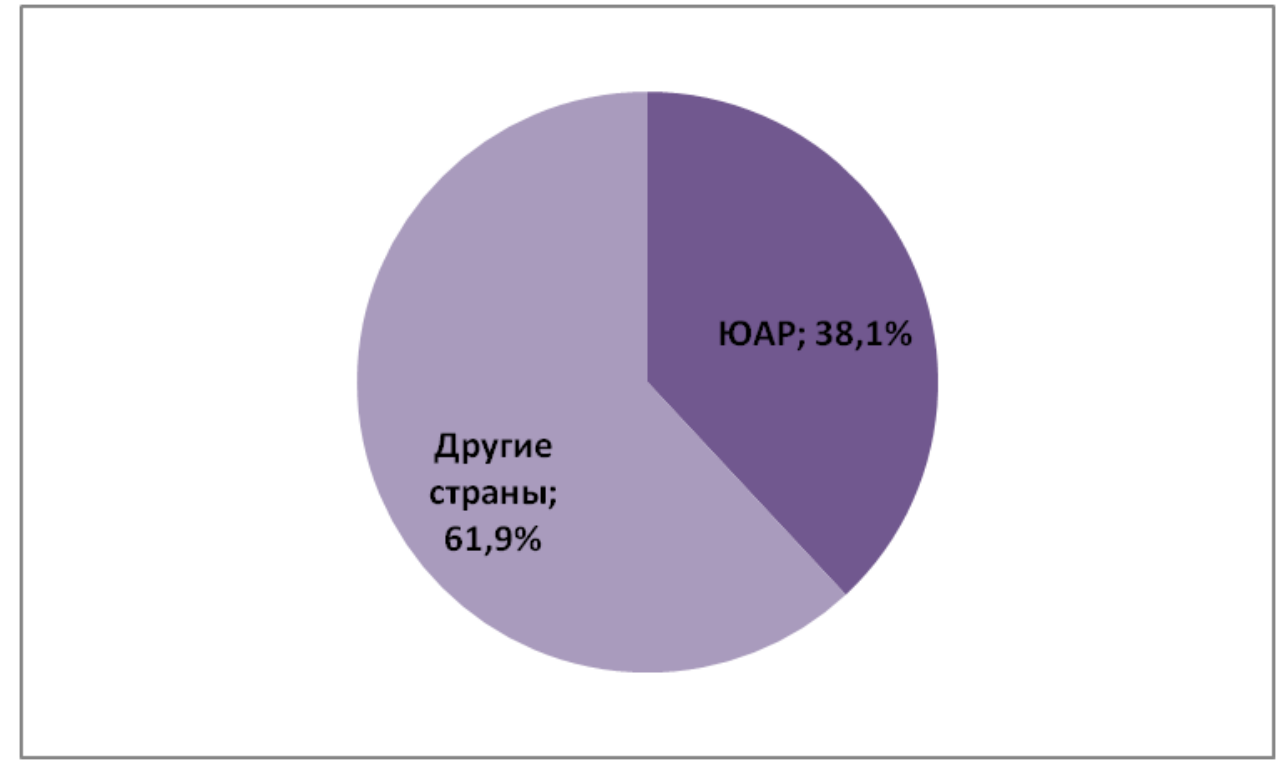

Рисунок 22 - Удельный вес ЮАР в структуре случаев, зарегистрированных за отчетную неделю в Африканском регионе

Наибольшее число заболевших на 1 млн населения за последнюю неделю зарегистрировано в Ботсване (3727) и на Сейшелах (3571). Наибольшее число летальных исходов на 1 млн населения за последнюю неделю зарегистрировано на Сейшелах $(40,8)$, в Либерии $(27,3)$, ЮАР $(26,4)$. 
Значительный рост заболеваемости в настоящее время отмечается в Анголе (рис.23).

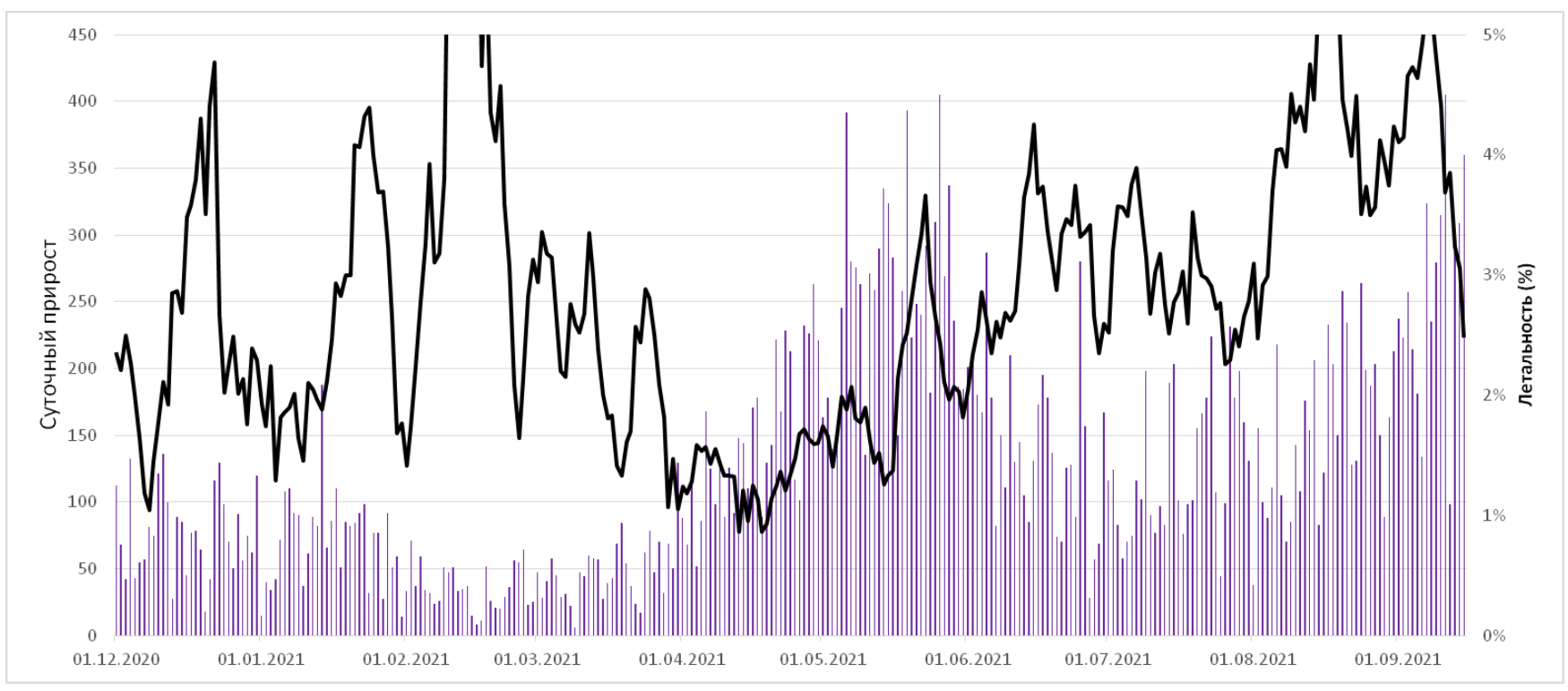

Рисунок 23 - Динамика ежесуточного прироста новых случаев заболевания и летальности в Анголе (как отношения средних показателей прироста смертей и случаев за 7-дневный период) 